
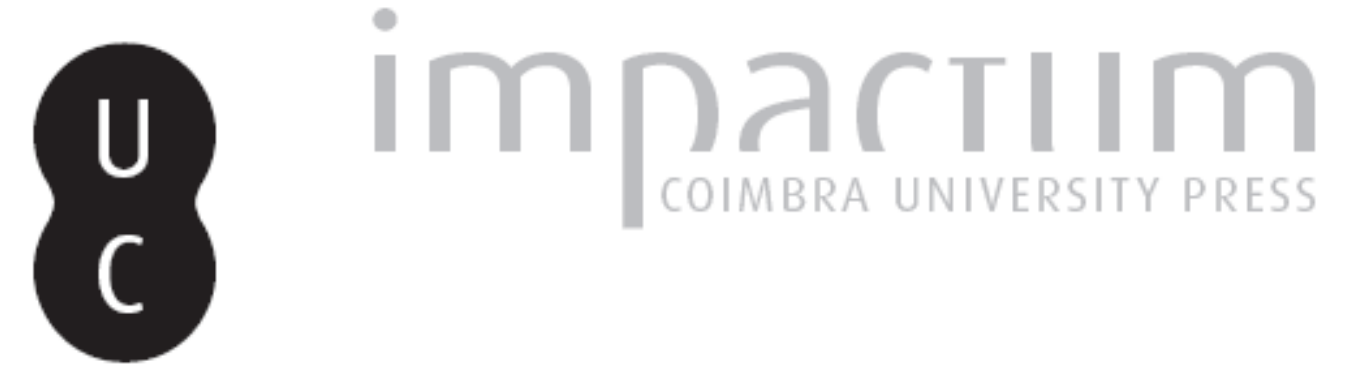

\title{
Contestação do regime e tentação da luta armada sob o marcelismo
}

\section{Autor(es): Bebiano, Rui}
Publicado por: Instituto de História Económica e Social; Imprensa da Universidade de Coimbra

URL persistente:

URI:http://hdl.handle.net/10316.2/44496

DOI:

DOI:https://doi.org/10.14195/0870-4147_37_4

Accessed : $\quad$ 26-Apr-2023 14:35:55

A navegação consulta e descarregamento dos títulos inseridos nas Bibliotecas Digitais UC Digitalis, UC Pombalina e UC Impactum, pressupõem a aceitação plena e sem reservas dos Termos e Condições de Uso destas Bibliotecas Digitais, disponíveis em https://digitalis.uc.pt/pt-pt/termos.

Conforme exposto nos referidos Termos e Condições de Uso, o descarregamento de títulos de acesso restrito requer uma licença válida de autorização devendo o utilizador aceder ao(s) documento(s) a partir de um endereço de IP da instituição detentora da supramencionada licença.

Ao utilizador é apenas permitido o descarregamento para uso pessoal, pelo que o emprego do(s) título(s) descarregado(s) para outro fim, designadamente comercial, carece de autorização do respetivo autor ou editor da obra.

Na medida em que todas as obras da UC Digitalis se encontram protegidas pelo Código do Direito de Autor e Direitos Conexos e demais legislação aplicável, toda a cópia, parcial ou total, deste documento, nos casos em que é legalmente admitida, deverá conter ou fazer-se acompanhar por este aviso.

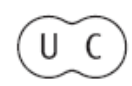




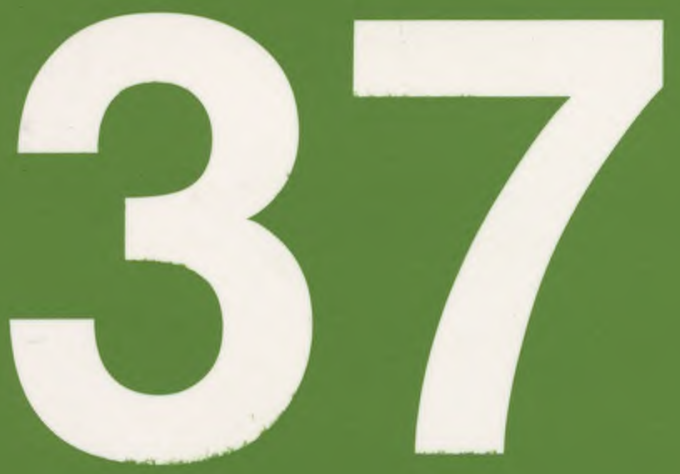

Revista Portuguesa de História

Faculdade de Letras da Universidade de Coimbra Instituto de Historia Econónica e Samial

Coimbra 05 
Revista Portuguesa de História

t. XXXVII (2005)

pp. $65-104$

\section{Contestação do regime e tentação \\ da luta armada sob o marcelismo*}

Rui BEBIANo

Faculdade de Letras da Universidade de Coimbra

"Se eu te pedisse a paz, que me darías?"

Casimiro de Brito, Jardins de Guerra (1966)

Entre o acidente doméstico que afastou Salazar do poder e o eclipse do Estado Novo, Portugal coabitou com a aceleração de um processo de mudança que o regime, se bem que pontualmente reformado e capaz de admitir em alguns momentos vozes destoantes, foi incapaz de entender e, menos ainda, de acompanhar. Num universo cerrado, submetido a uma persistente ordem policial, educado na suspeição perante o novo e o dissemelhante, sistematicamente resguardado da influência de modelos importados, acentuou-se ao longo desses seis anos a instalação de horizontes de transfiguração. Uma dilatação da mobilidade social e da concentração urbana, materializada a cadências diferenciadas, bem como certos indícios de reordenação nas áreas contíguas do poder e da oposição, marcaram a época, a par de alterações significativas no domínio das práticas culturais,

* Texto escrito no âmbito do projecto Culturas Juvenis e Participação Cívica - diferença, indiferença e novos desafios democráticos, a decorrer no Centro de Estudos Sociais com o apoio da Fundação para a Ciência e a Tecnologia. Colaboração na investigação de Alexandra Silva. 
articuladas com influências, visíveis e inevitáveis, que chegavam do exterior. Confluíram então tensões e enffentamentos que devem, pois, ser relacionados com as transformações profundas que ocorreram dentro e fora das fronteiras nacionais.

Ao mesmo tempo, perante um regime entrincheirado, manifestamente incapaz de se auto-regenerar, a percepção da luta armada como via de saída diante do bloqueio foi assomando enquanto possibilidade e foi também conquistando adeptos. Cenários e conjecturas acerca do impacte político da sua presença, qual tomou objectivamente plausível a revolução de 1974, irromperam então, no contexto de um potencial armazenado de conflitualidade. Recolhendo alguns dos seus ecos, poderá entender-se até que ponto, sem a presença material e simbólica da espingarda, os cravos que a ornamentaram na manhã do 25 de Abril jamais teriam preenchido a sua funcionalidade histórica.

1. Duas orientações de sinal contrário emergem na tentativa de produzir uma interpretação global para o lugar ocupado pela violência durante as cerca de duas décadas que preencheram os "longos anos sessenta", acompanhando a experiência da sua observação contemporânea. A primeira delas, menos positiva na apreciação que faz dos grandes eventos, tende a atenuar bastante o alcance histórico e a dimensão criadora das alterações ocorridas, acentuando, ao invés, as suas capacidades intensamente perturbadoras. Detecta-se em estudos como os de Todd Gitlin, que considera o período um tempo de cólera e de esperança, marcado por uma sucessão de dias "de um idealismo desenfreado ou de feroz destruição "(Gitlin, 1987: XIII), os quais associa a combates de grande efeito destruidor, desprovidos de objectivos claros a longo prazo. Lewis Feuer fala de uma "irracionalidade" e de "componentes auto-destrutivas" (Feuer, 1969: 102) detidos pela generalidade das movimentações, as quais entende imbuídas de capacidades regeneradoras mais próximas dos processos de auto-representação desenvolvidos pelos seus próprios actores do que de um efectivo impacte histórico. Um certo "conflito de gerações", marca indissipável do tempo, funcionaria assim como barómetro da substância, efectivamente frágil, das tensões que teriam assentado então, principalmente, numa brusca e desgovernada "revolução dos costumes" (Préel, 2000). Abordando o que entenderam como um "mau refluxo" da experiência sixtie, Luc Ferry e Alain Renaut insistiram ainda na vacuidade das múltiplas propostas de mudança avançadas na altura e no que lhes parece ser a sua quase completa irrelevância para o desenvolvimento das práticas políticas e culturais ulteriores, definindo uma tensão cronologicamente limitada, imersa em actos pontualmente aguerridos, mas quase sempre vivida no quotidiano de sectores sociais claramente circunscritos (Ferry e Renaut, 1988). Em muitos dos testemunhos que chegam da época, os seus actores insistem nesta 
perspectiva negativista, de acordo com a qual, como recentemente afirmou o romancista Jean-Paul Dubois, apesar da presença nas ruas do odor a pólvora e a gás lacrimogéneo, “o mundo não mudou, não mudámos a vida, mudámos talvez, e tão só, as nossas pequenas vidas "' (Dubois, 2005).

Inversamente, a segunda tendência afirma uma compreensão menos peremptória e bastante mais afirmativa no reconhecimento daquele tempo. Paul Berman procede, nesta direcção, a uma leitura hiper-optimista da intervenção criadora da consciência da utopia que dominou a época e que confluiu num amplo conjunto de iniciativas e de movimentos de uma natureza fracturante e frequentes vezes violenta (Berman, 1996). Esforçando-se por inventariar de maneira exaustiva as marcas que identificam aquela que considera haver sido uma fase de viragem global, Arthur Marwick sublinha, por sua vez, a coexistência, no seu interior, de fluxos contrastantes mas complementares, em condições de produzirem expressões de grande abertura, mas também debates e conflitos marcados por factores de acentuada agressividade, uns e outros integrando uma importante capacidade demolidora do quadro de valores dominante e dos grandes sistemas explicativos que, a partir dos alvores de Oitocentos tinham procurado construir um sentido para a trajectória das sociedades humanas (Marwick, 1998), apontando para momentos de redenção que se defrontavam abertamente com a ordem estabelecida.

É com base neste pressuposto que se tem procedido à identificação dos anos sessenta como uma fase marcada pelo questionamento radical das grandes metanarrativas e pela afirmação dos instrumentos políticos e culturais, característicos da pós-modemidade, que foram produzidos para servi-lo. A sua definição tendeu a substituir o formato antitético que detinham as grandes contradições da modernidade, tomando a forma do que Fredric Jameson, em The Seeds OfTime, apelidou de antinomias (Jameson, 1994). Estas corresponderiam a contradições de um tipo novo, que não mais detinham traços de mútua reciprocidade, de natureza hierárquica ou outra, ou mesmo uma capacidade dinâmica de resolução definida num terceiro termo sintético, mas que se decompunham, antes, de acordo com processos de separação crescentemente irreconciliáveis. Partindo desta ideia, Marianne DeKoven sugere que, na pós-modemidade, a estrutura binária que anteriormente definira a relação entre tirania e democracia, tal como entre conservação e revolução, teria sido profundamente alterada, dando lugar a uma "difusa, multidireccional, fluida, oscilante proliferação de formas de poder e de resistência” (DeKoven, 2004: 15), disseminada pelos múltiplos campos e espaços da actividade humana. Essa multiplicação teria conduzido à emergência de uma pluralidade de processos e à vivência de agudos combates. A tradição de uma "rebeldia sem causa", sem uma meta programática ou um objectivo histórico preciso - evocada no título original do popular filme de Nicholas 
Ray, estreado em 1955 com os rostos juvenis, dotados de uma nova expressão, de James Dean e de Natalie Wood -, foi projectada neste cenário.

A afirmação de critérios de diversidade poderia apontar - tem sido essa, de facto, a proposta dos sectores que tendem a desvalorizar as transformações da época - para o esbatimento da capacidade fecundante e da dimensão subversora das contradições produzidas. Para a afirmação de um tempo sedado de "paz e amor", de um cândido flower power, que pode ir hoje ao encontro de algumas das paródias que o processo de diluição da memória, acelerado no universo da cultura de massas, tem produzido a propósito dos ambientes daqueles anos. Todavia, muitos dos traços que os identificam, e que nos foram legados, apontam justamente na direcção oposta, integrando um conjunto de novidades, sensivelmente emergentes a partir da década de 1950, reconhecíveis em primeiro lugar nos países industrializados e nas áreas que lhe são imediatamente contíguas, as quais tenderam a subverter de uma forma fracturante os códigos éticos, os estilos de vida e as relações de poder, tal como a própria noção de autoridade. É neste contexto que Linda Hutcheon opera com conceitos como "complicitous critique" ( "crítica cúmplice "), "résistancefrom within ", "resistência a partir de dentro ") e "minoritarian and ex-centric" ( "minoritária e ex-cêntrica"), os quais associa a complexos processos de diluição da ordem estabelecida e do sentido da história produzidos a diversos níveis (Hutcheon, 1988). David Farber sublinha mesmo a natureza intensamente dramática de uma época, marcada pelo que designa como uma pesada "violência autodestrutiva", na qual foram modificadas, em grande parte por intervenção desta atitude, tanto a natureza como os critérios definidores da autoridade cultural e da legitimidade política, extremando-se também um vasto conjunto de contradições até se chegar ao manifesto enfrentamento (Farber, 1994a; 1994b).

Esta paisagem tem sido objecto de sucessivos reconhecimentos, cartografados através de contornos que se foram materializando com alguma constância. Se as dificuldades do pós-guerra e as tarefas de reconstrução produzidas a partir dos seus escombros impuseram transitoriamente um tempo de equilíbrios e de sobriedade, a exuberante emergência da nova cultura juvenil e a ampliação do consumismo definiram logo de seguida, em diversas regiões, um espaço de ousadia, de criatividade e de activa resistência, introduzindo profundas transformações no domínio dos costumes, do gosto e da moral. Ao mesmo tempo, sectores sociais emergiram de séculos de silêncio e de submissão: as mulheres, os operários, as minorias étnicas, religiosas ou sexuais, conquistavam então, a pulso, posições no terreno dos direitos civis, os quais, no complexo de avanços e de recuos que integraram, ultrapassaram sob múltiplos aspectos o ponto de não-retomo. $\mathrm{O}$ crescimento da classe média e a melhoria das condições materiais 
de existência de um núcleo importante da população, associados a inovações tecnológicas com rápidos reflexos no quotidiano, criaram condições para o alargamento e a diversificação do consumo, com consequências notáveis no domínio das práticas culturais e da distribuição do tempo útil entre o trabalho e o lazer, entrando em confronto com uma vivência que, nos seus traços mais essenciais, era ainda a imposta pela triunfante revolução burguesa oitocentista. Uma nova cultura de massas, centrada na actividade dos meios de comunicação, no espectáculo e nos ambientes culturais produzidos a partir do novo universo juvenil, produziu fenómenos de aproximação de natureza planetária e gradualmente transgeracional, tanto ao nível dos valores como dos comportamentos, construindo níveis de reconhecimento identitário capazes de erguerem novas solidariedades, tal como projectou metas diferentes e inquietantes, tanto a propósito das representações do mundo como do sentido das suas transfigurações. Diversas lutas pela emancipação nacional, integrariam igualmente este processo, produzindo uma nova ordem mundial, a qual, apesar de conter ainda algumas interferências dos enfrentamentos mais clássicos e bipolares da Guerra Fria, criaria renovadas metas e propostas, frequentes vezes em confronto com os poderes coloniais e os sistemas de troca dominantes. A realidade que emergiu, em 1955, da Conferência de Bandung, expressará cabalmente esta nova relação de forças.

$\mathrm{O}$ questionamento radical da ordem cultural e dos mapas políticos saídos do pós-guerra adquiriu, nesta direcção, uma acentuada dimensão fracturante, a qual é absolutamente central na interpretação global do período e na compreensão dos novos processos e das novas linguagens do protesto e do combate político (Stephens, 1998). As formas de resistência à ordem estabelecida que dominam os anos sessenta não podem, porém, ser identificadas apenas pela rejeição da ideologia e dos antigos programas políticos, qualificados como estéreis no quadro dos movimentos agora emergentes, os quais, aliás, nem sequer se encontravam a ser recusados de uma forma completa e liminar. Mas são-no também pela sua atitude de permanente busca de momentos e de processos múltiplos e contraditórios, materializando, no conjunto, uma "incoerência radical" (Clecak, 1973) que constituiu uma marca do período. Aliás, tanto os ambientes da contracultura como as importantes formas de activismo do tempo, combinavam, na sua iconografia como na fundamentação teórica que procuravam edificar, imagens, ideias e propostas capazes de misturar influências provenientes de diversas tradições culturais clássicas com elementos retirados dos produtos mais díspares da cultura popular urbana. Quando Jerry Rubin, o ex-activista de Berkeley, co-responsável pelo movimento Yippie $^{1}$ e pela campanha popular contra a presença americana * 
no Vietname, declarou haver retirado parte dos fundamentos do seu não-alinhamento de conteúdos de programas de rádio e de televisão acessíveis ao cidadão comum - "Não fui buscar as minhas ideias a Mao, Lenine ou Ho Chi Minh. Fui buscá-las ao Lone Ranger ”, escreveu em Do It! (Rubin, 1970:79) - não produziu uma paródia da sua própria biografía, mas exprimiu uma tendência transversal ao tempo e central, como parte integrante de uma "cultura do comum" em fase de rápida expansão (Williams, 1989), para o reconhecimento das suas conexões simbólicas e das suas características identitárias.

Os novos movimentos sociais, associados por Dalton e Kuechler a "um sector significativo da população que desenvolve e define interesses incompatíveis com a ordem política e social existente e que os prossegue por vias não institucionalizadas, invocando potencialmente o uso da força física ou da coerção " (Dalton e Kuechler, 1990: 227), integram agora esta orientação, traduzida na experiência de um activismo de natureza por vezes redentora e radical, outras vezes mais reactiva e epidérmica, mas procurando crescentemente escapar às categorias e aos processos desenvolvidos pelos combates travados pelo movimento operário e popular durante as longas décadas nas quais este foi essencialmente orientado e protagonizado por organizações políticas e sindicais de inspiração marxista. Boaventura de Sousa Santos sublinhou que a novidade maior desses movimentos sociais de novo tipo - tendo constituído "tanto uma crítica da regulação social capitalista, como uma crítica da emancipação social socialista tal como ela foi definida pelo marxismo " - consistiu, em primeiro lugar, na clara identificação de novas formas de opressão, "que extravasam das relações de produção e nem sequer são específicas delas, como sejam a guerra, a poluição, o machismo, o racismo ou oprodutivismo ", sugerindo tal realidade a instauração de um renovado paradigma social, que o autor considera "menos assente na riqueza e no bem-estar material do que na cultura e na qualidade de vida "(Santos, 1994:222). Em correlação com esta dimensão, disruptiva e intrinsecamente heterodoxa na sua historicidade, as noções de liderança, hierarquia e organização em curso na esquerda tradicional, não tendo sido apagadas dos programas políticos em vigor, foram directamente colocadas em causa.

As variantes da então designada nova esquerda desempenharam um papel crucial neste processo. Ainda que esta possa fundar parte substancial do seu heterodoxo corpo teórico e das suas múltiplas formas de organização e de actividade na tradição "velha " dos partidos e dos movimentos de inspiração marxista-leninista, assim como na longa experiência do movimento operário e popular, ela definiu uma rejeição do modelo tradicional de contestação. Esta rejeição colocou-a em posição de coincidência-sobreposição física e temporal (overlap) com o fenómeno contracultural, ampliando o seu lugar de denúncia e de objecção 
generalizada, de elevada visibilidade e potência conflitual, das contradições sociais (Stephens, 1998)2. Aliás, ambos os processos exprimiram uma clara insatisfação perante a crítica dominante do capitalismo. Denunciaram assim, na voz dos seus agentes - primordialmente jovens urbanos brancos da classe média-, uma experiência do capitalismo enquanto sistema opressivo, revelada nas múltiplas contradições por eles próprios vivenciadas. Não se referiam, todavia, ao capitalismo da produção em cadeia, mas sim a um capitalismo de novo tipo, consumista e expansivo, internacionalizado, transformado em alvo da crítica e do protesto. Detecta-se, desta forma, uma focalização reduzida sobre o sistema político em si mesmo e, em consequência, um interesse igualmente limitado em tomo dos processos que poderiam conduzir à tomada do poder, substituídos por um emaranhado complexo de motivações, as quais, frequentes vezes, já não integravam a límpida geometria do bem e do mal, do justo e do injusto, do revolucionário e do retrógrado - anteriormente em vigor - trocadas agora por "um sistema entrelaçado de oposições, de ambivalências, de significados múltiplos ", e, ao mesmo tempo, por "uma vontade de controlo imediato das condições de existência e das reivindicações de um espaço que indiciam uma independência do sistema" (Melucci, 1996: 95, 102).

Essa corrente que se pretendia radical, protagonista central do processo, sendo predominantemente um movimento de origem intelectual e urbana que teve entre os jovens a larga maioria dos seus dirigentes e militantes, procurou pois ultrapassar a tradição, longa e laboriosamente construída a partir das grandes comoções europeias do ano de 1848, de um combate prolongado e persistente pela tomada do poder, substituindo-o por um activismo arrebatado, impaciente, vocacionado para uma intervenção directa nas consequências consideradas nefastas dos desequilíbrios e das contradições do capitalismo, ou para a contraposição de um modelo inteiramente alternativo de matriz socializante. Exacerbou, por isso, o papel da acção directa, de uma natureza acentuadamente conflitual, na solução das questões de natureza táctica com as quais se vai sucessivamente confrontando. Emergindo de maneira visível em capitais de regimes tão díspares e geograficamente distantes como Paris, Praga, Nova Iorque, Tóquio, Berlim, Saigão ou a Cidade do México, os "novos esquerdistas" - sob alguns aspectos herdeiros históricos do "velho" anarquismo - partilhavam na sua diversidade, como lembrou Varón, "a oposição à opressão, o seu empenhamento na democracia participativa, e a utilização da acção directa como instrumento de protesto " (Varón, 2004:1), definindo-se, além disso, como activamente intemacionalistas.

2 A definição dramática do "novo" enquanto factor necessariamente positivo e que integra uma dimensão de ruptura num território de conflitualidade - nova esquerda, nova filosofia, nova história, novo cinema - passa nesta altura a integrar com regularidade o vocabulário critico. 
Estes definiram a sua policromática diversidade em tomo de cinco grandes vectores de afirmação, quase sempre combinados (Bebiano, 2003). O primeiro harmonizou-a com novas e divergentes leituras da teoria marxista, buscando adaptá-la aos conhecimentos científicos produzidos no século XX, em particular no campo da sociologia, da psicologia e da antropologia, procurando dissociá-la das fórmulas que haviam moldado os fundamentos da "velha esquerda", e desenvolvendo uma forte capacidade crítica, centrada não apenas na censura do sistema soviético, mas também no funcionamento da civilização tecnocrática, da sociedade de consumo e dos próprios limites e deformações da democracia representativa. O segundo eixo ensaiou o programa de um novo modelo de socialismo, o qual deveria insistir menos na revolução política e social, na tomada do poder e na estatização dos meios de produção, do que na transfiguração das relações humanas, ao nível do quotidiano individual, da vida em família, da experiência comunitária e das práticas sexuais. $O$ terceiro procedeu à definição de uma nova visão estratégica da mudança, visando a emancipação do indivíduo da tirania do colectivo, tomando-se as transformações no domínio do cultural uma condição que deveria antecipar as modificações de natureza social e política. O quarto assentou no desenvolvimento de um novo modelo de organização política: a esquerda que se pretendia nova via-se principalmente como um movimento, procurando intervir na acção, na consciencialização pela prática, no questionamento da ordem estabelecida pela via do exemplo e da provocação, recusando liminarmente a lógica do partido enquanto vanguarda organizada e instrumento central do combate político. Por fim, um quinto vector procedeu à identificação dos actores determinantes da mudança social, os quais deixavam de ser os proletários, ou essencialmente estes, tal como a ortodoxia marxista ocidental definira sem equívocos, passando a integrar o protagonismo de uma nova classe operária especializada, dos quadros técnicos, e sobretudo dos intelectuais comprometidos, dotados de uma aguda consciência da história, e de uma juventude estudantil plena de dinamismo no seu trajecto de afirmação social e na sua revolta.

Mas, acima de tudo, a radicalidade que este amplo sector protagonizava, procurou afirmar-se como forma de superação do modelo hegemónico protagonizado pelo marxismo-leninismo, assumindo-se, assim, como "sucessor de uma construção teórica que monopolizou praticamente a reflexão radical do último meio século e que constituía já a doutrina revolucionária predominante do meio século anterior " (Gombin, 1972:11 ). A prática dos seus partidários, que os partidos comunistas clássicos tão violentamente recusaram - leia-se a propósito O Radicalismo Pequeno-Burguês de Fachada Socialista, voluntarioso texto anti-esquerdista de Álvaro Cunhal, explícito no próprio título, com duas edições clandestinas, em 1970 e 1971, e outras posteriores - traduzia-se, 
sistematicamente, na recusa de um tacticismo que conduzia a alianças espúrias com sectores apenas reformistas e na defesa de formas imediatas de combate ao sistema político e social dominante. "Fazer a Revolução aqui e agora é o nosso propósito", proclamava-se em 1968 no seminal Obsolete Communism The Left Wing Alternative (Cohn-Bendit, 1968: 249-56), lido e debatido de maneira entusiástica nos mais diversos campus. Esta atitude determinava, naturalmente, processos de actuação de natureza espontânea, imediatista, e, como tal, ffequentemente errática. Mas conduzia também à afirmação, condicionada pelo seu radicalismo e pela completa oposição às formas sistemáticas de autoridade que se faziam sentir no domínio do quotidiano, de uma nova atitude perante o significado e a aplicação da violência.

A violência revolucionária situava-se, de facto, no eixo da caracterização teórica, do modus operandi e da motivação subjectiva deste hiperactivo sector de opinião (Scheper-Hughes e Bourgois, 2004: 17-19). Perante um universo que rejeitava de forma completa, recusando também os instrumentos de resistência e de intervenção que, particularmente dentro dos sistemas de democracia representativa, lhe eram oferecidos, todo o contrato que cerceasse o combate imediato era por ele enjeitado. O carácter grupuscular e sectário das formas de organização da esmagadora maioria dos seus activistas conduziria em situações diversas, como é frequente neste tipo de associações, à adopção de soluções de tipo messiânico e à valorização extrema do papel redentor e pretendidamente exemplar desempenhado pelas vanguardas armadas.

A experiência maoísta, a correr em diversos meios internacionais no decurso das décadas de 1960-1970 - estimulada, como ficou recentemente provado, pelos propósitos de Mao Tsé-Tung no sentido de transformar a República Popular da China numa superpotência e de hegemonizar o movimento comunista internacional (Chang e Halliday, 2005) - incentivará, com a sua teoria inflexível e bipolarizada da luta de classes, associada à defesa da guerra revolucionária como forma de alcançar e de manter o poder, o alastramento deste sentimento alargado, de acordo com o qual somente pela forças das armas se considerava ser possível transformar ou expurgar as imperfeições do mundo. $O$ próprio Mao sublinhou enfaticamente que o poder político apenas "nasce do fuzil" e que a guerra "só pode abolir-se por meio da guerra", constituindo o seu exercício "a forma suprema de luta para resolver as contradições " (Citações, 1972, parte V). Neste contexto, a extrema brutalidade da "Grande Revolução Cultural Proletária”, que percorreu toda a China entre 1966 e 1969, com alguns reflexos ainda na década seguinte, tomou-se um acto fundador com elevada capacidade de fascínio para os numerosos grupos de partidários do comunismo chinês espalhados um pouco por todo o mundo, em particular para aqueles 
oriundos dos meios universitários, acentuando a sua combatividade e a atracção que continuadamente viriam a manifestar pela força criadora protagonizada pela intervenção da violência (Dressen, 2000).

A influência da vitória da guerra de guerrilha em Cuba, concluida com a derrota de um regime dotado de um exército e de urna força aérea de tipo convencional, directamente apoiados pelo govemo imperialista dos Estados Unidos da América, conduziu, por outro lado, ao desenvolvimento de um certo "tropismo cubano ", particularmente caro, desde os fináis dos anos cinquenta, a grande número de jovens e de intelectuais de esquerda do ocidente, e que seduziu, enquanto modelo, sectores sociais significativos (Hourmant, 2000; Kurlansky, 2004). Mas levou também à atracção pelo modelo castrista da guerra de guerrilha, historicamente anterior na sua definição formal - que a América Latina tão bem conhecia já - mas que se havia transformado, sob novas condições, em objecto de um interesse particular por parte dos grupos que, pretendendo queimar etapas e servir de instrumento dinamizador de profundas e urgentes mudanças políticas, o tomavam como processo exemplar. A experiência da guerrilha urbana ou rural tomou-se assim objecto de grande atenção, definindo-se Che Guevara, ou figuras destacadas do Exército Republicano Irlandês e dos Black Panthers, como sinais da dimensão e da simpatia que esta forma de combate estava a adquirir, funcionando muitas vezes, particularmente entre a juventude, como motor de outras adesões. Femando Gabeira, escritor, jornalista, deputado federal do Rio de Janeiro, e antigo guerrilheiro urbano, recordou, em entrevista concedida em 1985 a Daniel Cohn-Bendit, que, tal como muitos dos seus companheiros, aderiu à luta armada, essencialmente, influenciado pela leitura de Révolution dans la Révolution, obra subtitulada "lutte armée et lutte politique en Amérique latine", publicada por Régis Debray em 1967, e pela persistente imagem romântica da experiência cubana. "Pensávamos ", dizia Gabeira, "que seria fácil aplicar ao Brasil e a todos os países da América Latina o modelo castrista ", até porque, como afirmava, "havia algo de fascinante nessa ideia" (Cohn-Bendit, 1988: 110). Em 1969, meses antes de morrer em São Paulo num tiroteio com a polícia, Carlos Marighella, líder do grupo armado Acção Libertadora Nacional, lançava um Manual de Guerrilha Urbana que em breve iria ser utilizado como cartilha em todos os continentes.

No limite desta atracção pela linguagem política das armas, o chamado terrorismo ganhou também partidários, ou, pelo menos, algum capital de simpatia, sobretudo no início da década de 1970, quando os poderes instituídos retomavam o controlo das formas espontâneas ou organizadas de dissidência. Como recordou Hans Magnus Enzensberger, muito diversamente do que é possível encontrar em boa parte das expressões de violência dos actuais grupúsculos, 
os guerrilheiros e os terroristas dos anos sessenta e setenta "achavam importante justificar as suas acções ", apresentando sempre os fundamentos ideológicos dos seus actos "em panfletos e proclamações, catecismos pedantes e declarações burocráticamenteformuladas " (Enzensberger, 1998:21), olhados como indissociáveis das formas e dos objectivos da luta armada. É verdade que a ideologia e a prática dos grupos terroristas podem ser considerados como "a antítese dos conteúdos emergentes nos novos conflitos", reproduzindo geralmente "a esclerose inevitável a exaltação doutrinária de modelos e de formas de organização ligadas à tradição sectária, a uma prática leninista rígida, a uma utilização doutrinária do marxismo" (Melucci: 1996, 270), mas, paradoxalmente, elas definem-se também como o resultado mais radical dos movimentos emergentes, uma vez que são "agentes da necessidade" (Varón, 2004: 10), produto de um bloqueio que teria levado os seus partidários a moverem-se no interior de um conflito que consideravam imposto pela repressão do Estado e pela ausência de resposta da parte do sistema político. Ainda que de reduzidas dimensões, organizações como a alemã Fracção do Exército Vermelho, as Brigadas Vermelhas italianas, o IRA, a ETA, ou os americanos do Weather Underground, foram objecto de alguma cumplicidade, ou pelo menos de um evidente fascínio, por parte de diversos sectores da opinião pública ocidental - em muitos casos nada suspeitos de partilharem dos seus métodos - ou de muitos meios de comunicação social e dos seus agentes no terreno.

Envolvendo este activismo mais circunscrito, a época legou também o testemunho de uma omnipresença da violência armada. A Guerra-Fria atingira a situação mais ¡mediatamente alarmante em 1961 -62, com a construção do muro de Berlim e a crise dos mísseis em Cuba, e, apesar da intensa corrida ao armamento e do equilíbrio imposto pelos interesses das duas grandes superpotências ter feito com que uma Terceira Guerra Mundial não passasse de uma conjectura, um latente "estado de guerra" tinha vindo a instalar-se, com uma sucessão de teatros conflituais disseminados pelos mais diversos pontos do planeta. Novos "tempos de cólera" emergiam, sob o aparente guarda-chuva aberto pela conjugação da actividade dos organismos internacionais com as acções da contra-informação e da espionagem, deslocando os territórios do conflito armado para paragens excêntricas em relação aos principais países industrializados. Do Vietname à luta independentista nas colónias portuguesas em África, passando pelos golpes e contras-golpes na América do Sul, pelos acontecimentos no Camboja, no Sahara Ocidental ou na Indonésia, instalara-se, porém, um espaço de conflituosidade do qual os meios de comunicação faziam crescente eco, concitando a atenção das populações informadas e construindo um ambiente no qual era possível reconhecer alguma familiaridade em relação ao papel dinamizador, 
por vezes emancipatório, dos actos de guerra. No interior dos próprios Estados Unidos o combate pelos direitos cívicos dos negros, que inaugurara em 1955 um novo tempo de enfrentamento da ordem segregacionista, desenvolvería, apesar do papel moderado da intervenção não-violenta de Martin Luther King, as características de urna resistencia que tendia a resvalar para o conflito, de que são testemunho a acção dos Black Panthers e de Malcom X, ou a acção sistemática da segregacionista $\mathrm{Ku}$ Klux Klan. Os tempos de détante, emergentes à escala mundial pelos meados da década de 1970, estabeleceram-se, em larga medida, sobre esse cenário prévio de convívio com o conflito e a guerra, diante do qual se procurou encontrar uma resposta, ao nível da política interna dos estados e das relações internacionais, capaz de os circunscrever e, na medida do possível, de os controlar (Aróstegui, 2001: 533-535).

Os movimentos estudantis participaram também, em larga medida, deste processo. Num texto de 1969, Hannah Arendt chamou a atenção para a potencialidade que, em termos de utilização da força como instrumento de combate político, o movimento estudantil começava então a deter, referindo como uma das suas particularidades "a nova e inegável glorificação da violência " (Arendt, 1985:12). Stephens refere que, dada a dimensão anti-autoritária, rebelde, de uma nova cultura juvenil em larga medida centrada nos campus universitários, o trabalhador, "como elemento revolucionário", se encontrava em alguns ambientes em vias de ser substituído pelo estudante como força motriz da mudança, estando este em vias de adquirir a potencialidade revolucionária que o marxismo originalmente atribuía ao proletário, enquanto Koss enfatiza o potencial revolucionário da aproximação das causas dos estudantes e dos trabalhadores (Stephens, 1998; Koss: 2002). Aliás, ainda em plena década de 1960 existira já quem sugerisse que os jovens universitários estavam a definir uma espécie de "novo proletariado", socialmente marginalizado e empurrado, por um conjunto de circunstâncias objectivas e subjectivas, para a actos de revolta anti-sistémica, chegando a proclamar-se que os mais radicais de entre eles se mostrariam, na perspectiva do seu envolvimento dinâmico, como "mais proletários do que o proletariado" (Kopkind, 1966: 8; Rowntree, 1968: 42). Flutuavam algures, em situação instável, do lado de fora das estruturas sociais que haviam sido determinadas pela organização da produção, dentro de uma situação de precaridade em relação à família e ao mundo do trabalho que reforçava - em contradição com a função tendencialmente integradora dos sistemas educativos de onde provinham - o seu elevado potencial subversivo. Alberto Melucci acentuará esta ideia, destacando o facto de haver sido ao longo daquele período que os sectores estudantis universitários, ainda que provenientes, em regra, de segmentos economicamente privilegiados, se haviam revelado os primeiros 
a perceber as contradições do sistema e a mobilizarem-se, de maneira particularmente activa, extremada e sistemática, contra ele (Melucci, 1996: 297-298).

Esses movimentos, bem como o universo político e cultural que definiram, potenciarão - de forma agudizada a partir dos acontecimentos mundiais do ano-charneira de 1968 - uma nova associação da juventude, ou de um segmento bastante significativo dela, a um "estado de ruptura" que, de acordo com Edgar Morin, parecia desenvolver "o jogo juvenil da revolução num mundo demasiado prosaico” (Morin, 1969: 108), gerando modalidades de rebeldia, construídas em nome de um novo iconoclasta, que se cria profundamente regenerador, materializado em práticas culturais que tendiam a rejeitar liminarmente as marcas do passado e a aderir a atitudes cívicas capazes de integrar uma forte componente de combatividade e mesmo de violência. Cartazes com os rostos de Mao, Lenine, Trotsky, Fidel, Guevara e Ho Chi Minh, ou de combatentes de causas mais localizadas, como os americanos negros Angela Davis e Malcom X, ou os republicanos irlandeses Bobby Sands e Bemardette Devlin, decoravam sedes de associações universitárias e quartos de residências estudantis, competindo, em regra com vantagem, com os ídolos da música e do cinema que só a geração seguinte viria a recuperar enquanto persistente envolvente iconográfica do seu quotidiano.

A defesa militante da paz como forma de resistência à autoridade dos governos e ao seu belicismo, que após uma época de afirmação em redor da Primeira Grande Guerra praticamente desaparecera com a luta de extremos em que se viria a transformar a Segunda, retomava o seu curso, apoiada em algumas das correntes culturais emergentes na década de 1960 e particularmente centrada na campanha mundial de oposição à participação americana no conflito do Vietname. No prefácio, não assinado, à edição portuguesa de Diálogo ou Violência?, contendo o texto integral das conferências e dos debates que tiveram lugar em 1963, durante os Encontros Internacionais de Genebra para discutir precisamente a temática da paz, sublinhava-se que "há temas que demandam a acção; por isso, há que proclamá-los para que eles não fiquem esquecidos" (Diálogo, 1965: 9). A notoriedade pública que, na época, envolvia o já nonagenário filósofo Bertrand Russei, como activo opositor da corrida ao armamento e da guerra do Vietname, ou a auréola de que gozou Martin Luther King, integravam-se justamente nesta tendência. A encíclica Pacem in Terris, publicada pelo papa João XXIII em Abril de 1963, bem como os debates e resoluções do concílio Vaticano II acerca da paz, do ecumenismo e da justiça social, haviam estimulado também a adesão a soluções de uma natureza não-violenta para os conflitos que se encontravam por resolver. Todavia, esta tendência para sublinhar as virtualidades da paz constituiu, de facto, uma resposta débil perante os complexos antagonismos e o potencial de violência que a época vinha conhecendo. 
Retomando a uma ideia avançada no início - o sinal circular da paz como alegoría dos anos sessenta - se exceptuarmos a ideia original do movimento hippie e o proselitismo de alguns grupos religiosos, falou-se efectivamente pouco, no contexto das fórmulas de luta política que dominaram a época, de uma capacidade regeneradora da paz como valor absoluto e enquanto objectivo programático. No estudo monumental que escreveu sobre a experiência global dos anos sessenta, o historiador britânico Arthur Marwick abordou essa presença sistemática da violência ao longo de todo um capítulo, significativamente titulado "Liberdade, turbulência e morte". Mas considerou que, ampliada com a exacerbação das contradições materializada ao longo do ano de 1968, ela foi imposta pelas circunstâncias e agravada pela incompreensão dos sectores mais conservadores da sociedade e pela brutalidade das forças policiais e dos tribunais. Por vezes, também por uma interferência de estados de euforia e de uma propensão para o heroísmo individual inerentes a uma fase na qual, em parte como acontecera na fase criativa do movimento romântico, a consciência de pertença a um tempo de mudança e de nele se ter um papel decisivo a desempenhar, era muito forte (Marwick, 1998: 533-536). Esse estado era ampliado pela consciência, possibilitada pela explosão da informação, em particular pela generalização da televisão, de integrar agora um movimento anti-autoritário, antisegregacionista, antisistémico ou anticolonialista - traçado à escala do planeta. Neste contexto, o uso da força mais extrema passava a ser entendido como instrumento regenerador. Como escreveu Jean-Paul Sartre em 1961, no prefácio à edição francesa do influente manifesto emancipatório Les Damnés de la Terre, de Frantz Fanon, alastrava no tempo uma "violência nova", aquela que, "tal como a lança de Aquiles, tem o poder de cicatrizar as feridas que ela própria abriu” (Sartre, 2002: 36).

2. O carácter internacional deste conjunto de alterações, associado então à nova realidade comunicacional, vai fazê-las repercutirem-se até mesmo no interior de espaços nos quais o carácter acentuadamente autoritário do Estado e a vigilância exercida sobre os mais diversos aspectos da vida social, subordinada a regimes de partido único, firmemente empenhados no controlo do acesso à informação e no bloqueio da formação de uma opinião pública livre, faria supor uma penetração difícil, lenta, ou mesmo impossível. Os ventos de mudança - traçando uma analogia com o título da conhecida canção de Bob Dylan $^{3}$ - haviam sido, em larga medida, produzidos nos principais países

${ }^{5}$ The Times TheyAreA-Changin ' permanece ainda como hino de uma rebeldia geracional, frequentes vezes utilizado como banda sonora em filmes ou programas de televisão versando o universo sixtie. 
industrializados, por via de regra em sociedades consideradas abertas e sob regimes assentes em diferentes modalidades de democracia representativa, mas haviam feito sentir-se também no interior de Estados que se encontravam muito longe dessa caracterização, como era o caso do Brasil e da Argentina, na América Latina, da Checoslováquia, da Hungria e da Polónia, dentro da Europa do "socialismo real", ou em Espanha e Portugal.

No nosso país, a exiguidade de estudos detalhados e diversificados sobre o período tem conduzido à afirmação dominante, principalmente nos média, de leituras um tanto superficiais e, não poucas vezes, assentes em algumas mistificações. Uma destas prende-se com a suposta estabilidade total do regime, apenas perturbada por factores extemos condicionados pela guerra colonial, por uma crescente contestação estudantil de natureza semi-legal e pelo esforço clandestino da oposição, protagonizado principalmente pelo Partido Comunista e, em áreas específicas, pela iniciativa pulverizada, mas ao mesmo tempo hiperactiva, da esquerda radical. É um facto que, observada a partir das declarações dos responsáveis pelos órgãos do Estado, parece detectar-se uma aparência de estabilidade, mas, como se verá de seguida, ela foi em larga medida ilusória. Outra ideia pré-concebida é materializada num certo tipo de devaneio acerca da época por parte de minorias que a viveram de uma forma particularmente intensa, enunciando uma ebulição que, na realidade, era invisível para a generalidade da população e, ainda assim, confinada sobretudo às mudanças operadas em 1968, após a retirada de cena de Salazar. Mas a verdade é que as grandes transformações culturais dos anos sessenta, mesmo quando adaptadas, também aqui haviam chegado, alterando o ambiente social, produzindo uma cultura de oposição em larga medida renovada, e, ao mesmo tempo, introduzindo algumas modificações na evolução política do país (Bebiano, 2003).

A aproximação a este processo seguiu duas vias essenciais. De um lado, as mudanças mundiais e os processos comunicacionais alteraram a situação de aparente imutabilidade tão caro à perspectiva da realidade nacional que o antigo presidente do Conselho tanto prezava e que pretendia preservar como modelar. Do outro, um conjunto de características próprias do regime tendia a acentuar as contradições, algumas novas, outras agravadas, afastando do seu programa um número crescente de cidadãos, incluindo neles sectores que situavam à direita do espectro político a sua crítica ao regime.

A "primavera marcelista" veio acelerar este movimento: a ténue liberalização da actividade política e do regime censório, a renovação da actividade económica e da política educativa, a contemporização com um sindicalismo mais independente e a tentativa de abertura ao mundo suscitaram rapidamente reacções de sinal contrário (Rosas, 1994:545-558). Na área do poder, assistiu-se gradualmente 
a alguma recuperação por parte dos sectores mais conservadores, empenhados em resistir à mudança, enquanto no território social que se tinha vinha distanciando do regime se renovava a convicção da possibilidade, se não mesmo da inevitabilidade, da sua queda. Da aparente insuperabilidade deste conjunto de contradições, ampliada pela inflexão autoritária notada a partir dos finais do ano de 1970, se definiu a consciência de que uma efectiva mudança poderia, definitivamente, tomar imprescindível o exercício redentor da intervenção armada.

Pode reconhecer-se este panorama seguindo a emeigência e desenvolvimento de três factores de integração de representações da violência armada no quotidiano dos portugueses, acentuados agora na sua visibilidade e na afirmação das suas capacidades dinâmicas. O primeiro consistiu no agravamento da conflitualidade interna e na ampliação do próprio convívio com informações sobre a violência armada que iam chegando do exterior; o segundo relacionou-se com o dramático e permanente impacte da Guerra Colonial nos processos de defesa e de contestação do regime; o terceiro, por fim, integrou os dilemas tácticos colocados na actividade dos sectores políticos que se lhe opunham abertamente.

\subsection{Conflitualidade interna e informação}

O Estado Novo foi eiguido, dentro de uma dinâmica que considerava revolucionária, sobre uma imagem essencialmente quietista e ensimesmada da sociedade portuguesa, a qual procurava continuadamente preservar, e, se possível, reproduzir. Estudos produzidos nas últimas décadas, particularmente no domínio da história política, social e literária, tendem a relativizar esse ecologismo radical de um "viver habitualmente", tal qual Salazar o desejara, que corresponderia a um ideal de quase-retomo aos arcaicos cenários de aldeia traçados na distante década de 1860por Júlio Dinis. Autopia de Monsanto, “aldeia mais portuguesa de Portugal”, julgada "fortaleza moral da nossa terra, síntese das virtudes da raça, nossa rígida bandeira de pedra" (Monsanto, 1947; Cunha, 2001: 31-62), marca da exemplaridade do mundo rural, essencialmente confinada aos ritmos repetidos da "faina agrícola, sujeita à torreira do sol ou à impertinência das chuvas que é acima de tudo uma vocação de pobreza ", humílima mas orgulhosa por saber que "só ela alimenta o homem e lhe permite viver" (Salazar apud Melo, 2001,46), jamais terá sido plenamente cumprida. Todavia, foi no decorrer da década de 1960 que se viu definitivamente abalada na ilusória inexpugnabilidade da sua própria definição.

Os anos sessenta em Portugal - nunca será de mais sublinhá-lo - foram anos de uma rápida e, para os padrões do país, profunda mudança. Esta foi imposta por um conjunto complexo de alterações de natureza política, social e cultural. 
No campo político assistiu-se ao recuo do Estado paternalista, ao surgimento de um sector de opinião mais "liberal", ao revigoramento da oposição (em particular do PCP), à emergência da esquerda revolucionária, ao crescimento do movimento reivindicativo estudantil, ao incremento das formas de resistência no mundo do trabalho. Por sua vez, a sociedade "sociedade dualista em evolução" da qual falava Sedas Nunes - vincadamente espartilhada entre uma área "tradicional", ainda influente junto do poder político e no interior do universo rural, mas já em nítida fase de involução demográfica e económica, e uma outra, "moderna", já mergulhada num processo incontomável de crescimento, embora detectável apenas em espaços urbanos e sectores sociais restritos (Nunes, 2000:25-84) - pontuava um dinamismo integrador de novos ritmos de industrialização e de concentração urbana. No campo das práticas culturais as transformações seriam particularmente sensíveis e evidentes, com o aparecimento de uma cultura juvenil de pendor cosmopolita, de uma diversificação da cultura das elites, da perda de dinamismo dos sectores mais conservadores, da instalação de uma produção cultural independente do regime, de alterações notáveis no domínio das políticas educativas, bem como nas áreas da informação e da edição, e do aparecimento da visível de novos códigos estéticos.

A esta mudança de cenário não foi alheia a emergência de universos alternativos, determinados por um conjunto de factores sociais e demográficos que pesaram bastante no aparecimento de uma outra dinâmica, como aconteceu com os novos fluxos da emigração de retomo, particularmente aquela que se dirigia para a Europa - que entre 1965 a 1974 atingiu a média anual de saídas, ponderando conjuntamente a emigração legal e a ilegal, de cerca de 122 mil pessoas em cada ano (Baganha, 2000) - e pelos factores de inovação e de reconhecimento de expressões de diferença determinados pela nova realidade do turismo de massas, cujo impacte vinha alterando, sobretudo durante os meses do Verão, a paisagem humana e cultural. Estes foram factores que, por si só, possibilitaram um convívio assíduo com a instabilidade e o reconhecimento de modalidades alternativas de desenvolvimento. Todavia, apenas pela sua intervenção, tais modificações não suscitariam alterações profundas no confronto com um mundo exterior conflitual e em estado de ebulição, não fora, em larga medida, o profundo abalo vivido na mesma altura no domínio da comunicação social.

Desde meados da década, mas principalmente a partir de 1968, com o arranque da "primavera marcelista", começam a multiplicar-se na imprensa, mesmo em alguma daquela que não se opunha declaradamente ao regime, informações constantes, relacionadas com os grandes conflitos internacionais do período, do Vietname à Palestina, da Irlanda do Norte à América Latina e a muitas outras paragens, ou com as lutas sociais observáveis nas mais diversas partes 
do planeta. Publicações de grande circulação, como o Diário de Noticias e O Século, em Lisboa, ou O Primeiro de Janeiro e o Jornal de Noticias, no Porto, vespertinos lidos pelas elites desafectas ao regime, como o Diário de Lisboa, o República ou o Diário Popular, revistas e jomáis como a Vida Mundial, o Noticias da Amadora, o Jornal do Fundão ou o Comércio do Funchal, mesmo uma publicação mais conservadora como o semanário Observador, para além do novíssimo Expresso, fundado já em 1973, mantinham essa presença, em relação à qual não era raro exprimirem-se atitude de crítica ou de simpatia que corresponderiam às expectativas de pelo menos parte de cada um dos respectivos públicos leitores. A título de exemplo, pode notar-se como o Comércio do Funchal, apoiado numa ampla carteira de assinantes e muito lido nos meios da esquerda heterodoxa, exprimia, em Agosto de 1970, a sua simpatia pelos jovens militantes tupamaros, em luta contra o Estado uruguaio: "um certo gosto pelo mistério não é negável nestes jovens apaixonados, resolutos e sobretudo convencidos de que é impossivel analisar e compreender a sua acção utilizando os esquemas habituais " (CF, 1970, 2076: 8).

Uma parte da actividade editorial acompanhava de perto este processo. A edição da não-ficção, particularmente aquela dada a conhecer por algumas editoras mais dinâmicas e desvinculadas dos sectores conservadores da sociedade, como a Prelo, a Presença, a Centelha, a Inova, a Portucalense, a Ulisseia, as Edições 70, a Dom Quixote, e outras, teve igualmente um papel determinante na construção de uma opinião mais informada em relação aquilo que se passava para lá das fronteiras, e também mais capaz de contornar os mecanismos de controlo e formação propostos pelo Estado. As Publicações Dom Quixote, iniciando a actividade editorial em 1969, com livros de um grafismo mais apelativo, colecções especificamente voltadas para os conflitos e problemas contemporâneos, as preocupações da juventude ou a renovação de diversas áreas do conhecimento, e traduzindo importantes artigos de revista e estudos teóricos publicados intemacionalmente (como fazia com os "Cadernos D. Quixote" e os "Novos Cadernos", ou com as colecções "Diálogo" e "Universidade Aberta"), obtiveram um êxito assinalável neste domínio - indispensável para a abertura a novas formas de pensar e de agir -, ainda que a actividade censória tivesse por diversas vezes forçado, mesmo durante a "primavera marcelista", a que algumas das edições figurassem nos catálogos com a etiqueta "fora do mercado", passando a uma venda directa feita de forma geralmente sub-reptícia.

Porém, e apesar dos limites impostos pela censura, era através da televisão que se desenvolvia o processo mais visível de abertura ao mundo. A Radiotelevisão Portuguesa desempenhou um papel fundamental na apropriação dinâmica de referências espaciais que se situavam para lá das fronteiras nacionais, integrando, 
como nenhum outro instrumento dentro do território nacional, as mutações da época que privilegiavam a nova cultura de massas e o papel da juventude, notícias e imagens de conflitos extramuros, difundindo internamente as novas modas e, ainda que de forma controlada, alguns dos ecos de processos de contestação vividos no exterior. A insistência paralela no valor da ruralidade ou na do bairro popular, ampliada pelo sucesso de popularíssimas peças de teatro televisivo, dotadas de enredos capazes de suscitar essa aproximação, que tinham ainda um lugar destacado na programação, era também contrariada pela citação das imagens atraentes de uma vida situada num alhures citadino e plural. Esta era facultada pelos noticiários, pelas longas-metragens mostrando planos de grandes urbes, ou por séries com enredos definidos enquanto narrativas de viagem e de aventura, como as americanas Missão Impossível e O Fugitivo, ou as britânicas Danger Man e O Santo, as quais integravam, por via de regra, a programação de maior êxito popular. Ao mesmo tempo, as séries de aventura em formato policial, de espionagem, de novela histórica ou de western, possibilitavam também um reflexo de tempos e de lugares de diferença, aventura e vibração, pouco consentâneos com a quietude da realidade envolvente, e capazes de alimentar uma imaginação de alteridade e de divergência.

A par destes processos, a própria militarização do regime, claramente ampliada como consequência da Guerra Colonial, acentuou a percepção de um tempo no qual o conflito armado, e as suas circunstâncias, não constituíam algo ao qual os portugueses pudessem permanecer imunes, ainda que informados desde a instrução primária sobre o carácter negativo, ou mesmo medonho, dos “desvarios" belicistas dos tempos da Primeira República, que o salazarismo teria afastado do horizonte da vida nacional. Os demorados e solenes desfiles militares do 10 de Junho, "dia da Raça”, serviam também para estabelecer essa presença, ao que não era igualmente alheia a perspectiva de cumprimento de um serviço militar obrigatório excepcionalmente exigente e extenso, em regra de um mínimo de três longos anos, e a constante intervenção no quotidiano dos mecanismos de polícia, em particular no que respeita à presença, visível ou previsível, dos agentes da PIDE-DGS.

\subsection{O impacte da Guerra Colonial}

Como se escreveu num dos primeiros livros editados em Portugal que abordaram sistematicamente o assunto, "as Forças Armadas assumiram a guerra colonial e a politica que lhe estava subjacente ao longo de cerca de 13 anos " (Guerra, 1993:337), presumindo estas, após a abortada tentativa do golpe do general Botelho Moniz, em 1961, a impossibilidade de uma contestação alargada que pudesse colocar o regime em perigo. "O Ultramar não se discute ", havia declarado 
peremptoriamente Salazar, enquanto Caetano, ao recusar publicamente, na «Conversa em Família» de 15 de Novembro de 1972, a possibilidade de "negociar com terroristas "4, adiantava que "tal negociação é impossível, sacrílega!", uma vez que os movimentos não passariam de "bandos reunidos para servir interesses alheios, empregando a violência " (apud Guerra, 1993:317). Todavia, esta guerra era, cada vez mais, uma "presença invisível", quase espectral, dada a forma como era vivida sem quase ser nomeada, e que introduzia no horizonte das famílias a perspectiva do afastamento prolongado ou da morte de alguns dos seus entes queridos, tomando-se um factor de angústia e descontentamento que a oposição não podia deixar de ter presente e de utilizar nos seus combates contra o regime.

A maior parte desta afirmava uma solidariedade para com os movimentos de libertação que identificava o fim da guerra e o estabelecimento da paz com uma inequívoca vitória da opção armada dos movimentos independentistas (Bebiano, 2002). Porém, a atitude da generalidade da oposição não-comunista permaneceu durante bastante tempo, algo equívoca. Para este heteróclito sector anti-salazarista, ainda com expectativas em relação à possibilidade de uma evolução democrática do regime, a questão colonial surgia como problema incómodo. Os sobreviventes do republicanismo, reunidos à volta do que restava dos apoiantes da campanha de Humberto Delgado, não admitiam o abandono puro e simples dos territórios coloniais, enquanto os socialistas, mostrando-se um pouco mais ousados, se mantinham ainda assim bastante hesitantes a propósito do problema. O jornal Portugal Socialista falava muito pouco do conflito, por comparação com o impacte que este vinha mantendo no quotidiano dos portugueses e na cena internacional, evitando combatê-lo directamente dentro do país. Condenava-se, é certo, "a guerra injusta e sem saída para que o governo de Salazar arrastou Portugal, incluindo aquela parte do povo que labuta dignamente nas colónias " (PS, 1967, 2: 1), e adiantavam-se cenários futuros, num "Portugal moderno e re-europeizado ", integrando "uma comunidade luso-brasileira, na qual caberiam ainda os futuros Estados nascidos, porauto-determinação, das colónias portuguesas" (PS, 1967, 4: 6), mas excluía-se qualquer campanha intema que pudesse contestar o conflito.

Uma posição igualmente ambígua - cuidadosa, de acordo com alguns pareceres - será evidenciada nos II e III Congressos da Oposição Democrática, realizados em Aveiro nos anos de 1969 e 1973. O primeiro será praticamente omisso em relação ao tema, na sequência de uma "Plataforma de acção comum

\footnotetext{
${ }^{4}$ Como tem sido revelado mais recentemente, conversações com os movimentos independentistas foram afinal ocorrendo em diversos ritmos e ocasiões.
} 
da Oposição Democrática", resultante de uma reunião preparatória, na qual apenas numa proposta colocada em $25^{\circ}$ lugar se pedia a "resolução pacífica das guerras do Ultramar, na base do reconhecimento dos direitos dos povos à autodeterminação, precedida de um amplo debate nacional " (apud Cadernos Necessários: 1970, 5). No Congresso de 1973, todavia, notou-se já alguma preocupação com o assunto por parte de diversos participantes, principalmente os próximos do Partido Comunista, se bem que das conclusões tenha sido excluída uma clara tomada de posição. Num total de 155 páginas, apenas numa delas, já quase no termo do documento, se refere a urgência em "empreender uma larga campanha sobre as consequências da guerra colonial (...), o desenvolvimento de uma ampla campanha nacional exigindo o fim da guerra e (...), a denúncia dos crimes de guerra cometidos pelo exército colonial "(III Congresso, 1973: 142).

Menos constrangidos pela censura e pela repressão policial, alguns sectores activistas católicos evidenciaram um maior empenhamento público na mobilização de vontades contra a guerra. Do já mencionado impacte da encíclica Pacem in Terris, dos debates e resoluções do concílio Vaticano II, bem como da política de aggiornamento da Igreja protagonizada principalmente por Paulo VI, havia brotado algum estímulo à procura de soluções pacíficas e consensuais para os conflitos coloniais que se encontravam por resolver. Em 1970, a atitude do papa, ao receber em audiência os representantes dos movimentos de libertação das colónias portuguesas, não pode ter deixado de causar profunda impressão naqueles que, neste campo, duvidavam já da justeza das posições do governo, traduzíveis em diversas iniciativas de alguns sacerdotes e de grupos de leigos. De qualquer forma, estas posições anti-guerra tomavam sempre a forma de uma resistência passiva, ou de reflexão critica, mas jamais a de uma propaganda sistemática, organizada e com objectivos práticos claros. Evitava-se aqui a proclamação explícita de uma posição mais violenta de "guerra à guerra"

Ao invés, o Partido Comunista definiu uma atitude de simpatia e de indefectível apoio às posições dos movimentos independentistas. Desde o início do processo, partilhava da ideia segundo a qual a emancipação dos povos coloniais e a luta do povo português pela sua liberdade, possuindo um adversário comum, se encontravam estreitamente associadas. Logo em finais de 1961, a propósito dos acontecimentos da índia, considerava o Avante! que "se a Nação não se levantar urgentemente para dizer não à política fascista e colonialista do governo de

5 Palavra de ordem abusivamente utilizada em 1972 num panfleto, assinado por um "grupo autónomo de estudantes", que se propunha ampliar, num sentido bastante mais politizado, a solidariedade para com o grupo que havia ocupado a capela do Rato na noite de 30 para 31 de Dezembro de 1972. 
Solazar, à guerra sangrenta e interminável de Angola e à guerra de Goa, seguirse-ão inevitavelmente outras guerras coloniais ", cujo resultado final só poderia ser "um desastre nacional para o povo português " (A, 1961, VI, 311:2). No mesmo número surgiam já, como irá sucederá em muitas edições posteriores, notícias sobre formas de resistência à guerra- recusas ao embarque, levantamentos de rancho, propaganda nos quartéis, e outras formas de luta - bem como um artigo no qual se denunciam as iniciativas excepcionalmente violentas de ocupação militar, de "colonização dos militares ", que estavam a ser aplicadas no norte de Angola. Assunto retomado em outro texto, onde se dará conta de atrocidades cometidas pelas tropas portuguesas e apelará, pela primeira vez, a que os próprios soldados exijam "o fim do massacre colonial", voltando, se preciso for, "as armas contra os oficiais colonialistas que os comandam, exigindo o fim da guerra colonial e o seu regresso à metrópole ” (A, 1962, VI, 314:4).

Gradualmente, porém, o discurso sobre a Guerra Colonial foi ultrapassando a oposição pontual a uma situação que o PCP considerava atentatória dos interesses vitais do povo português e dos direitos nacionais dos povos das colónias, para aproximar os dois campos de luta. Em artigo publicado em O Militante nos finais de 1964 essa posição era já bastante nítida, acentuando-se aí, a partir do axioma de Marx segundo o qual "não pode ser livre um povo que oprime outros povos", que os interesses dos sectores da burguesia monopolista ligada à exploração colonial se articulavam com o poder que esta internamente detinha. Escreve-se, por isso, que Portugal "seria um país mais progressivo se não tivesse colónias ", e, em consequência, que a guerra colonial representava "um centro onde vão dar todas as lutas da classe operária e do nosso povo” (M, 1964, 130: 8-10).

A forma de o PCP conduzir a luta interna contra a guerra irá, no entanto, sofrer algumas alterações. A definição programática de uma "Revolução Democrática e Nacional", estabelecida em Setembro de 1965 durante o VI Congresso, com base no relatório de Álvaro Cunhal intitulado Rumo à Vitória, identificava e ordenava as tarefas do partido, nelas atribuindo um papel ao "reconhecimento aos povos das colónias do direito à independência " e às formas de resistência à guerra empreendidas por militares no activo, mas entendendo não ser esta uma batalha absolutamente prioritária (Cunhal, 1979). Portugal, "país colonizador e colonizado ", que "tem um Ultramar porque é um 'Ultramar 'para os outros ", deveria assim abandonar esta segunda condição, para melhor poder anular a primeira. Defendia-se que se abatesse o regime para se poder depois dialogar com os outros.

Radica aqui a indesmentível evolução da atitude dos comunistas face ao problema da deserção. Por razões políticas e de consciência, o tema será levantado 
por diversas vezes. Pelos anos de 1965-1966 a defesa da deserção como atitude louvável ou mesmo revolucionária, anteriormente considerada inquestionável, passa a ser temperada pelo enquadramento desse momento de resistência individual nos objectivos políticos partidários. Neste sentido, será fundamental a publicação, no Militante, de um documento que tinha como título a expressão programática: “Criar uma forte organização militar é uma das tarefas mais urgentes do Partido ".

Atribui-se neste texto uma enorme importância à organização dos comunistas nos quartéis e à propaganda junto dos soldados, apontando um conjunto de objectivos: "contra a guerra das colónias, contra a violência das manobras e exercícios militares, contra as injustiças e vexames vindos dos oficiais e comandos fascistas, contra a intromissão de oficiais estrangeiros e a instalação de bases estrangeiras em território nacional, contra a política de traição nacional do governo fascista, contra o terrorismo político e a repressão, contra a ausência de liberdades democráticas. Mas é o tema de deserção aquele que maior desenvolvimento merece no documento. Declara-se assim: "E sabido que o partido não só se não opõe, mas preconiza e aplaude a deserção de soldados, sargentos e oficiais que não querem participar nas criminosas guerras coloniais. (...) A organização de deserções colectivas (...) devem portanto continuar $e$ intensificarse tanto quanto possível”. Esclarece-se porém que o partido "no que se refere aos seus militantes, não pode apoiar a deserção quando ela se faça isoladamente ", uma vez que tal corresponderia, na sua opinião, a privar muitos jovens de serem esclarecidos, dentro das próprias forças armadas, sobre o carácter negativo da política colonial do governo. Diz-se mesmo o seguinte: "Na luta contra a guerra colonial, os comunistas têm de ir tão longe quanto possível, inclusive até àsfrentes de batalha, sempre com o objectivo de esclarecer os outros soldados que não devem combater, que não devem arriscar a vida para defender os interesses dos monopolistas e outros inimigos da Pátria Exclui-se igualmente a deserção antes de se assentar praça ou mesmo da ida à inspecção, perguntando: "como conciliar a atitude destes camaradas com os objectivos da revolução se eles fogem inclusive a aprender o manejo das armas? ”(M, 1966,141: 1-3).

$\mathrm{O}$ desenvolvimento de posições de combate mais directo contra as guerras coloniais, por parte dos comunistas, travar-se-á ainda dentro de um outro enquadramento organizativo. Concretamente através da sua actividade dentro da Frente Patriótica de Libertação Nacional (FPLN), proclamada em Dezembro de 62 e com sede estabelecida, a partir de 64, em Argel. Em 1965 começa a ser editado o boletim Passa Palavra, "órgão dos militares da FPLN", que sugere formas de organização e de protesto, nomeadamente através da recusa à disciplina, mas que, durante algum tempo, evitará sugerir a deserção. Esta tomar-se-á, após o abandono dos sectores próximos do general Delgado, uma das bandeiras 
da Frente. No primeiro número, o Liberdade, órgão oficial da renovada FPLN, trará um artigo no qual o tema é levantado de forma clara (L, 1966,1), e algum tempo depois o assunto merecerá urna clara sugestão: "Para qué continuar a sofrer nesta maldita guerra? (...) Desertemos!" (PP, 1968, s.n.), exclama, mencionando dados impressionantes sobre o volume de refractários e de desertores. Pouco antes, tinham já sido divulgadas sugestões de combate contra a guerra claramente próximas das propostas do PCP: "Finge que combates, mas evita tanto quanto possas perseguir os patriotas africanos. (...) Organiza a deserção e a revolta contra a guerra (...). Procura o contacto com os movimentos de libertação e prepara a tua deserção e a daqueles camaradas da tua confiança " (Idem). $\mathrm{O}$ movimento de fuga de jovens em relação à incorporação no exército e à mobilização para a guerra colonial era na altura, de facto, fora do comum: em 1961 a percentagem de faltosos foi de 11,6\%, em 62 subira já para 12,8\%, em 1963 atingia os $15,6 \%$, em 1964 subia para 16,5\%, entre 1965 e 1968 rondaria os 19\%, e entre 70 e 72 andou sempre muito perto dos $21 \%$ \{Resenha, 1988:254-270).

Entretanto, em 1970, numa altura em que se toma inevitável a saída dos comunistas das actividades da FPLN, toma-se pública a actividade da Acção Revolucionária Armada (ARA), criada pelo PCP para a luta armada "contra o fascismo, o colonialismo e o imperialismo ", e que tomará as instalações militares como alguns dos seus alvos. A organização terá dado os primeiros passos algum tempo antes, mas só nessa altura começa a levar a cabo operações de impacte, destinadas a desestabilizar o regime e voltadas "directamente contra a máquina de guerra colonialista " (A, 1972, VI, 435:2). Nesta direcção, seriam feitos atentados contra o navio de transporte de tropas Cunene, um armazém de equipamento militar da Companhia Colonial de Navegação, a Base Aérea no. 3 de Tañeos, o Quartel-general do Comiberlant em Oeiras e um outro depósito de material de guerra, situado em Alcântara. Como recordou Jaime Serra, as principais acções da ARA tiveram "por alvo preferencial objectivos relacionados com o apoio à luta contra a guerra colonial, 'poupando ', por esta razão, o aparelho repressivo do regime fascista " (Serra, 1999: 127). Cerca de um ano após a ARA ter desencadeado a sua primeira acção, também as Brigadas Revolucionárias (BR), próximas de uma FPLN que se havia então afastado já do PCP, levavam a cabo, a 7 de Novembro de 1972, uma primeira iniciativa armada contra instalações da NATO na Fonte da Telha, considerada em comunicado como acto de "solidariedade entre o povo português e os povos das colónias". Formadas em meados de 1970, as Brigadas irão infligir diversos golpes no regime, tomando como alvo sistemático das suas acções diversas instalações militares \{apud Guerra, 1993: 371-377).

Todavia, a organização de uma acção anticolonialisca visível, construída à margem do PCP, tinha começado mais cedo, principalmente nos meios 
estudantis e junto dos emigrados políticos. Os sectores ligados ao PCP, centrando em larga medida a sua acção no combate semi-legal contra as políticas educativas do governo, não a colocavam como tarefa prioritária, tomando assim menos difícil a organização de combativos grupos estudantis da esquerda radical, os quais colocavam, eles sim, a "guerra à guerra" como eixo da sua actividade.

Tal aconteceu com a participação de um grande número de organizações e de facções da extrema-esquerda, principalmente com as de tendência maoísta, que haviam tido a sua génese em 1964, após a criação do Comité Marxista Leninista Português (CMLP) e da Frente de Acção Popular (FAP), construídos com base na iniciativa de dissidentes do PCP, sendo o mais destacado de entre eles Francisco Martins Rodrigues, ex-membro do secretariado do Comité Central do PCP e que havia participado na fuga de dirigentes comunistas de Peniche que em Janeiro de 1960 reconduzira Álvaro Cunhal à liberdade (Pereira, 2005: 702-732. Desde os primeiros documentos, a temática anticolonialista encontrase inscrita em contornos grossos na agenda deste sector, sendo essa uma das marcas de divergência em relação às posições dos comunistas. Em Outubro de 1964, o primeiro número, do Revolução Popular, órgão do CMLP, declara que “o começo das guerras revolucionárias de libertação dos povos das colónias portuguesas assinalou a passagem a uma nova fase da luta antifascista em Portugal ” (RP, 1964, 1: 3). A posição imediatamente defendida foi a de que a luta armada dos movimentos independentistas se deveria articular com o combate armado dos revolucionários portugueses.

Terá sido, no entanto, no interior do movimento estudantil, bem como nas suas áreas sociais e culturais contíguas, que, no início da década seguinte, o combate anticolonial protagonizado por esta corrente assumiu maior expressão. De facto, o movimento conheceu, a partir do ano lectivo de 1970-1971, um processo de visível e acentuada radicalização (Cardina, 2005). Apesar de dura repressão governamental - que, para além das prisões efectuadas, incorporará compulsivamente nas forças armadas muitos dos seus principais dirigentes e activistas - a "crise de 69", vivida em Coimbra, exprimira ainda reivindicações de uma natureza principalmente reformista, voltada para objectivos mais especificamente estudantis. Coincidindo com a "primavera marcelista" e com os ecos longínquos do Maio de 1968, que então chegaram ainda bastante filtrados. Foi preciso esperar pelo novo endurecimento do regime, coincidente com nova tentativa de sufocar o movimento associativo estudantil, com o agravamento dos combates coloniais, em particular na Guiné, e com esse impacte dos acontecimentos de Paris, por via da propaganda política e do retomo ao país de algumas das suas testemunhas, para se assistir a uma rápida e acentuada politização do meio. Entraram nesta altura em cena, dentro do movimento, 
palavras de ordem que colocavam radicalmente em causa o regime político e o sistema económico vigentes, tomando-se a luta anticolonial uma preocupação constante deste movimento ultra-politizado.

Os maoístas vão-se afirmar, apesar da dispersão organizativa e das suas complexas clivagens intemas, como a corrente que, neste campo, manifestará uma maior radicalidade e ousadia de processos. Os Cadernos Necessários, afectos a sectores heteróclitos mas que se situavam politicamente à esquerda do PCP, haviam dado já o mote, atribuindo um enorme destaque, nos cinco números policopiados que saíram entre Junho de 1969 e Março de 1970, à questão colonial. A sua iniciativa de maior impacte foi a publicação clandestina de cinco grossos cadernos e um volume de textos, com tiragens de mil exemplares que corriam depois de mão em mão, dedicando sempre uma atenção muito grande ao problema da guerra e à circulação de informação a respeito das suas condicionantes e desenvolvimentos, declarando-se aí, desde o início, querer dessa forma contribuir "para o alargamento de um movimento de resistência e oposição à guerra (...) ea favor de uma descolonização completa " (Cadernos, 1975:28). Não sendo os Cadernos uma publicação de natureza partidária, a profusão de citações combinadas de obras de Lenine, de Estaline e, mais veladamente, de Mao, assim como a evolução futura de alguns dos seus colaboradores, permite estabelecer alguma proximidade em relação aos grupos que, dentro do meio estudantil, retomavam a herança de um activismo à esquerda do PCP e, de certa forma, também contra o PCP. Isso mesmo percebeu Álvaro Cunhal, ao decidir-se a criticar com veemência os Cadernos, declarando que, "para estes radicais pequenoburgueses a única tarefa é a 'revolução popular que derrube a ordem capitalista e fascista " ", e que, até lá, "nada haveria a fazer da parte dos portugueses, além da publicação de uns tantos 'Cadernos ' teorizantes ”' Cunhal, 1971:60).

Nesta mesma direcção, a União Revolucionária Marxista-Leninista, resultante de uma das cisões do antigo CMLP, empenhar-se-á desde o início no combate anticolonial, ainda que, ao contrário dos restantes grupos "marxistas-leninistas" e do próprio PCP, não propusesse a deserção como atitude defensável. "Desertar é apenas uma atitude individualista e oportunista”, declara, uma vez que, segundo considerava, "é em Portugal, nos seus locais de trabalho (..), que os trabalhadores portugueses terão de lutar Além disso, este grupo entendia que a saída das fileiras "conduz necessariamente à perda de elementos com os quais a Revolução Proletária poderia contar". No caso dos jovens que procurava influenciar serem destacados para a guerra, estes deveriam então, no seu próprio teatro, levar a cabo um conjunto de acções de natureza violenta consideradas revolucionárias: "continuação da propaganda contra a guerra colonial, sabotagem, espionagem, aniquilamento de bufos e elementos importantes do 
exército, interferência nas operações, estreita colaboração com os movimentos de libertação, etc., etc. " (FC, 1971, 2).

A Organização Comunista Marxista-Leninista Portuguesa (OCMLP), caracterizada por um comportamento mais pragmático e voluntarista, usará por sua vez o seu jornal clandestino, $O$ Grito do Povo para divulgar eventos relacionados com a guerra, sempre que estes eram desfavoráveis ao exército português, apelando continuadamente, uma vez mais, para a deserção. Em acções de rua ocorridas principalmente no Porto e em Coimbra - manifestações-relâmpago, pintura mural de slogans, distribuição de propaganda - os seus militantes procuravam alargar o reconhecimento da sua posição no campo da luta anticolonial. Ligados também à OCMLP, os Comités de Luta Anti-Colonial e Anti-Imperialista (CLACs), divulgarão, em 1973, um conjunto de três tarefas políticas que mostrará a radicalidade das suas propostas de luta: "1. Apoio político aos movimentos de libertação traduzido na defesa da sua justa causa, na divulgação dos seus programas politicos junto dos trabalhadores portugueses, na divulgação das vitórias alcançadas pelos movimentos de libertação (...), no combate aos pacifismos (...); 2. Combate ao chauvinismo incutido pela burguesia nas massas, ao social-chauvinismo 'de esquerda'dos oportunistas (...) e todos os neo-colonialistas (...), ao imperialismo e ao social-imperialismo; 3. Propaganda pela recusa de defesa da pátria imperialista, fomentando a deserção após a instrução militar, fazendo agitação no seio do exército colonialista, sabotando o esforço de guerra da burguesia, defendendo junto dos trabalhadores a necessidade de derrota do exército colonialista português " (PCV, 1973, 1). $\mathrm{O}$ posicionamento da organização revelava também uma das características essenciais do sector - coincidente aliás com as dos modelos chinês e albanês que pretendia seguir - que é a extrema animosidade, aliás recíproca, experimentada em relação às posições "revisionistas" do PCP.

Tal atitude será fulcral na propaganda política do Movimento Reorganizativo do Partido do Proletariado (MRPP), fundado em 1970. Esta organização, caracterizada por um profundo sectarismo em relação à generalidade da restante esquerda e por uma linguagem pleonástica e triunfalista, que decalcava, um pouco à maneira da Esquerda Proletária francesa e do seu jornal La Cause du Peuple, as palavras de ordem e orientações estereotipadas dos comunicados dos comunistas chineses nos anos da Revolução Cultural, desenvolveu de uma forma crescente a sua própria propaganda contra a guerra, presumindo para si própria uma condição de vanguarda - "anti-imperialista" e "anti-social-imperialista" - desse combate. Em 1971, os dois primeiros números do jornal Luta Popular são exclusivamente consagrados à "grande, gloriosa e justa luta revolucionária de libertação nacional dos povos oprimidos das colónias ", servindo a data de 
uma manifestação contra a guerra que tinha sido convocada pelo movimento para "marcar o início da condução proletária da luta contra a guerra colonialimperialista " (LP, 1971,1 e 2).

Entretanto, à margem das proclamações da imprensa partidária e da organização de uma oposição no terreno aos conflitos coloniais, ou em complemento delas, outra forma de resistência à guerra vinha fazendo o seu caminho. Num crescendo constante, esta tinha lugar desde logo nos meios urbanos e entre os intelectuais e a juventude, sobretudo a estudantil ou aquela, ainda sem um rumo de vida definido, que pouco tempo antes deixara as universidades e que, em muitos casos, fora integrada nas forças armadas. Tratava-se de um sector naturalmente mais sensível à continuação do conflito - que o atingiria de uma forma ou de outra - e, ao mesmo tempo, mais aberto a influências políticas e a formas de rebeldia as quais nem sempre pela via das organizações políticas de oposição ao regime iam chegando.

Nesta direcção, a literatura que se produzia em Portugal vinha também contribuindo para criar uma percepção crítica do conflito. Femando Assis Pacheco, em Cuidar dos Vivos, de 1963, e Manuel Alegre com a Praça da Canção, de 65, e $O$ Canto e as Armas, de 67, foram de facto os precursores da produção literária de configuração claramente anticolonialista e compreensiva em relação à opção militar dos independentistas (Teixeira, 1998:5), com textos que, principalmente no segundo caso, tiveram, como se viu, poderosa influência no alargamento do campo que se opunha à continuação do conflito. Em 1966, aliás, sai Jardim de Guerra, um livro de poemas de Casimiro de Brito preocupado igualmente com a proximidade da violência militar. Todos eles autores, como alguns outros, próximos de uma oposição que jamais aceitou pactuar com uma solução militar e unilateral dos conflitos em curso.

A envolvência de um importante sector da sociedade por uma posição de resistência à guerra, ou de enfrentamento dos seus partidários, foi, pois, suscitada, estimulada, preparada, nos planos político e cultural, pelas diversas oposições de esquerda. E, por isso também, foram as propostas que estas vinham elaborando - todas no sentido de uma articulação da rápida independência das colónias com a transformação revolucionária da sociedade portuguesa - que vieram a determinar, em larga medida, o ritmo e o rumo tomado pela política de descolonização no pós-25 de Abril.

\subsection{Os dilemas tácticos da oposição}

Ocorria, nesta altura, uma conflituosidade interna que seria acentuada pela desilusão suscitada em amplos sectores pela derrota não prevista de Humberto 
Delgado e, principalmente, com a ampliação dos processos de contestação e de combate em relação à ordem estabelecida, os quais não deixaram de se intensificar ao longo da década de 1960, em particular nos seus derradeiros anos, sobretudo entre os trabalhadores e os estudantes universitários.

A articulação entre este desenvolvimento conflitual e a irrupção de perspectivas acerca da necessidade objectiva de empreender acções armadas para pôr termo ao bloqueamento do regime, toma-se então uma realidade. Exceptuando o aproveitamento táctico das eleições, sempre muito condicionadas pelo regime, que ocorreram em 1969 e em 1973, e certos esforços no campo da actividade semi-legal em áreas pontuais - alguns sindicatos, associações de estudantes, cooperativas de consumo e grupos de intervenção cultural - a maior parte da oposição tendia a considerar que não existiam condições para um derrube do regime por via de reformas, e, menos ainda, como efeito de um processo eleitoral que pudesse ser aceite como minimamente livre e credível. O antigo debate, presente na actividade da esquerda europeia, principalmente antes da Segunda Mundial, a propósito da alternativa entre reforma e revolução, deixava aqui de fazer sentido, substituído antes pela discussão acerca do tipo de revolução que seria possível e desejável, e do grau de violência necessário para a tomar vitoriosa. Os próprios socialistas, ou pelo menos parte importante deles, pareciam conformarem-se com essa situação. Em Março de 1972, no Portugal Socialista, afirmava-se mesmo que "a verdade é que para fazer entender a uma ditadura qualquer coisa é necessário devolver a violência sofrida a quem dela tiver o monopólio " (PS, 1972,31: 6), e cerca de um ano depois encaravam-se aí com simpatia as acções violentas - das quais se falará adiante - da ARA, da LUAR e das Brigadas Revolucionárias. "Estas acções", declarava-se, "mostram o agudizar inevitável de uma luta de dezenas de anos" (PS, 1973, 36: 8).

Aposição do PCP, sem qualquer dúvida a oiganização oposicionista com maior capacidade de intervenção e uma articulação sistemática e prolongada com o combate social, é particularmente significativa, se se considerar a sua permanente recusa, comum aliás à táctica da generalidade dos partidos comunistas ortodoxos que na época actuavam dentro das democracias ocidentais, de quaisquer formas de radicalismo obreirista e de aventureirismo político. Recusando todas as propostas de acção anti-regime que sugerissem a necessidade, como sublinhou Álvaro Cunhal ainda em 1964, de o partido se preocupar com a tarefa de "escaldar as imaginações " (Cunhal, 1979:239), assume-se, todavia, que a par da "luta de massas", pontual ou sob a forma de campanhas, se tomava imprescindível a preparação da queda do regime pela via da força armada.

Esta orientação estratégica ficou definida no âmbito dos trabalhos preparatórios do VI Congresso do partido, realizado em 1965, a partir do relatório escrito pelo 
seu secretário-geral intitulado Rumo à Vitoria. Nele se consagra urna parte substancial às questões relacionadas com a necessidade da violência na definição das tarefas políticas. Dos 14 capítulos que o integram, 4 deles abordam exclusivamente esta temática, tratando um a guerra colonial (cap. VI), um segundo o "o levantamento nacional, perspectiva revolucionária do movimento antifascista" (cap. X), um outro “a luta popular de massas, motor da revolução ” (cap. XI) e, por fim, um outro ainda os cuidados a tomar perante os eventuais desvios golpistas e aventureiristas (cap. XIII).

Reconhece-se, logo no inicio do capítulo $\mathrm{X}$, que “o povo português há muito está convencido de que, para derrubar a ditadura fascista e instaurar a democracia, será necessário o recurso à força ", uma vez que Portugal era um Estado fortemente centralizado e com "uma ditadura fascista ", dotada de um aparelho militar, policial e judicial organizado e depurado, que impedia quaisquer liberdades ou reclamações, as quais recebiam sempre "a violência como única resposta ", e onde os círculos governantes manifestavam um completo autismo diante das propostas da oposição e a mais firme determinação em resistir-lhes, se necessário fosse, pela força das armas. Afirma-se então que "sópor ingenuidade imprópria de dirigentes politicos se poderia pretender desarmar e vencer um bandido armado até aos dentes e de armas aperradas empurrando-o com as mãos" (Idem, 171). Seria pois a determinação dos governantes em defenderem até ao fim o regime "através de uma política terrorista" a impor, de uma forma incontomável, "o seu derrubamento com uma solução violenta ” (Idem, 172-173).

Esta violência seria concebida pelo PCP de distintas maneiras, orientadas em quatro direcções. Duas delas não carecem aqui de um tratamento mais desenvolvido, uma vez que se ocupam de situações de alguma forma vagas: uma referia-se às precauções de autodefesa e às iniciativas tácticas que, perante a inflexibilidade do regime, as acções reivindicativas poderiam ver-se forçadas a conter; a outra dizia respeito às condições de tomada do poder no caso de uma ainda hipotética, e previsivelmente distante, situação insurreccional. Mas as duas seguintes requerem outra atenção, uma vez que se confundem com condições e iniciativas que, alguns anos volvidos se viriam de facto a materializar.

A primeira delas permanece ainda mal conhecida. Ainda no mesmo capítulo do Rumo à Vitória, Cunhal fala abertamente do trabalho político a efectuar dentro das próprias forças armadas, junto das quais se verificariam "inúmeras lutas de soldados e cada vez mais frequentes acções de resistência dos oficiais ", sendo, por tal motivo, possível "ganhar a tropa para a causa da revolução democrática " e, acima de tudo, necessário criar ali “a disposição para a luta decisiva contra a ditadura" (Idem: 181). Situação que o partido não deixaria 
mais de procurar acautelar. Em 1970, aborda o modo como "a conquista de posições no aparelho militar é necessária para o agravamento da crise do regime (...) e, numa perspectiva mais larga, para a criação de condições subjectivas favoráveis ao levantamento nacional, à insurreição popular armada " (A, 1970, VI, 418: 7), vincando, dois anos depois, a necessidade de efectuar trabalho político no interior das tropas, uma vez que este "mina a principal base de apoio do fascismo e do colonialismo " (A, 1970, VI, 442: 7). Daí também, aliás, o já mencionado cuidado do PCP em propagandear como princípio a possibilidade da deserção. Continua, pois, por conhecer a real dimensão desse trabalho - já em Janeiro de 1966 O Militante anotava que "criar umaforte organização militar é um das tarefas mais urgentes do partido " (M, 1966, 141) - e o grau de presença dos comunistas nas forças armadas, aspecto essencial para esclarecer mais completamente a preparação do derrube militar do regime e dos acontecimentos revolucionários que se lhe seguiram.

A segunda diz respeito à actividade da ARA. Se bem que, como se viu, esta se tenha concentrado em actividades de sabotagem do esforço de guerra do governo, partia de pressupostos mais gerais, que a situavam como um grupo de "acções especiais" do partido, consequente com as já enunciadas posições acerca do papel da luta armada. Criada por decisão de uma reunião do Comité Central, foi a sua direç̧ão entregue a Jaime Serra, membro da Comissão Executiva do PCP. Em texto publicado já em 1999, este retoma a linguagem e as decisões do VI Congresso, falando da justeza da "utilização da violência revolucionária " diante do "uso e abuso da violência e do terror contra os trabalhadores ", bem como da integração das acções na "criação de condições que, no desenvolvimento da luta política geral, conduzissem à insurreição popular armada" (Serra, 1999: 23 e 29-30; e Narciso, 2000). Verifica-se, todavia, uma preocupação constante com a separação entre a experiência desta oiganização, que se pretendia "ligada à luta das massas " e a precipitação protagonizada pelos sectores da esquerda radical que viam de uma forma mais directa o papel da violência. É curioso como, procurando sublinhar tal diferença, Serra se concentra em aspectos como a clara separação, ao nível do armamento operacional, entre as cuidadosas "cargas explosivas, cuja composição e potência eram suficientes para derrubar, perfurar ou incendiar os objectos em vista ", que a ARA utilizaria, e "a bomba, um invólucro (...) carregado com explosivos ou projécteis metálicos que, ao explodir, espalha uma carga mortífera ” (Idem: 31), a qual constituiria recurso utilizado tradicionalmente pelos sectores esquerdistas e aventureiristas.

Cunhal manterá também um particular cuidado em tomar clara a diferença entre a atitude oficial do seu partido diante da utilização da força armada e as 
declarações e iniciativas dos sectores políticos mais radicais acerca do assunto. Considera, em O Radicalismo Pequeno-Burguês de Fachada Socialista, que esse uso não pode ser aplicado de forma irreflectida, em acções intempestivas concebidas apenas no papel, sendo de combater "a impaciência pequeno-burguesa, o vicio do verbalismo, o culto da frase revolucionária, a doença infantil de "queimar etapas»", e vincando que essas iniciativas requerem sempre "a força material, a força organizada, para se lançar ao assalto, ou seja, um exército político ligado às massas e as massas radicalizadas para a luía pelo poder, para a insurreição " (Cunhal, 1971: 32-33). Sendo, portanto, por não se verificarem tais condições, ainda cedo para se avançar nessa direcção.

Essa não era, todavia, a posição dos sectores da oposição contestados directamente por Cunhal, os quais equilibravam a efectiva precaridade da sua organização, por vezes o seu isolamento das lutas travadas dentro do país, com um intenso activismo e a radicalidade de um discurso que sublinhava sempre a premência, e a possibilidade imediata, do uso da violência armada enquanto instrumento para promover o derrube do regime. A FPLN, após o abandono dos comunistas, avançara justamente nessa direcção, utilizando a sua imprensa, e as escutadas emissões de rádio da Voz da Liberdade, para promover esse tipo de iniciativa. De início, Manuel Alegre, um dos seus principais activistas, declarava apenas, em termos ainda algo vagos, que "para andar para a frente è preciso fazer uma revolução em Portugal ” (L, 1966,3-4:10), mas, em breve, o Liberdade declarava que era preciso "passar do reconhecimento teórico à preparação prática, das palavras aos actos ", vincando a necessidade de transformar a resistência antifascista "em luta popular, em insurreição armada" (L, 1967, 6: 2). Nos fins de 1967, Alegre esclarece ainda, apropriando-se da conhecida frase escrita por Marx na Contribuição para a Crítica da Filosofia do Direito de Hegel, que "a luta armada é uma forma de luta política, a passagem «da arma da crítica à crítica das armas»". Aceitando que "não é a partir da luta armada epor si só que se pode concluir do carácter revolucionário de uma dada linha política ", assevera que "a insurreição armada é o objectivo estratégico principal do movimento antifascista português, na fase actual de luta" (L, 1967, 8: 1 e 10). Fernando Piteira Santos, por sua vez, insistirá em que "contra o poder tirânico, contra a opressão, o terror, a exploração e a miséria, são legítimas a resistência e a revolta ", definindo esta, com clareza, como "um movimento de massas organizado que atinja no seu desenvolvimento as formas violentas, às formas superiores de luta: a greve revolucionária, a insurreição popular armada" (L, 1968, 11: 1 e 7). Em Outubro de 1969, no artigo "Para o levantamento armado", António Barracosa retomará estas ideias, invectivando no final do texto, de um modo particularmente inflamado, 
os seus leitores: “Basta de sofrimento. Basta de crimes. Ao ataque, portugueses! ” (L, 1969,16: 16).

Entretanto, Alegre publicara já, em 1967, O Canto e as Armas, expressivo título de uma das obras mais lidas e relidas do poeta, a qual funcionou, nos anos terminais do regime, como leitura de cabeceira de um grande número de opositores do regime (depois parcialmente musicada, em 1969, pelo cantor de intervenção Adriano Concia de Oliveira). Aí se fala de um "amor militante” queé "Amor rebelde amor guerrilha amor Guevara ”, das “armas harpas que são precisas ”, de um "Tempo de viver ou morrer (...) tempo de romper as malhas " que lhe parecia aproximar-se: "Chega um tempo febril. Fabril. Tempo de síntese. Tempo de guerra. Tempo de mudança ” (Alegre, 2000:212,220,225). Tempo para a acção, portanto.

A esquerda radical tinha, acerca do carácter imperativo da luta armada uma posição igualmente clara, assumindo algumas das posições que Cunhal criticara. O CMLP demarca-se claramente do Partido Comunista centrado na contestação de uma das propostas de Rumo à Vitória. Propunha-se neste texto a preparação de uma etapa política, definida como a de uma Revolução Democrática e Nacional, não necessariamente violenta, ou não-violenta na sua essência, que seria dotada de uma base social de apoio o mais ampla possível, obtida através daquilo que o PCP passou então a designar como a "unidade de todos os portugueses honrados". Esta linha táctica definirá porém, para Martins Rodrigues, "uma linha para a liberalização burguesa e um rompimento total com o marxismo " (Rodrigues, s.d.: 75), que o CMLP contesta em nome de uma Revolução Democrática-Popular subordinada à aliança operário-camponesa, que constituiria a base social de uma mudança operada necessariamente pela via da força armada. Recusava-se assim a ideia de um "levantamento nacional", sugerida pelo PCP, trocada pela proposta de uma "insurreição popular antifascista", fundada na actividade de um "exército revolucionário" e destinada à conquista do poder, uma vez que "a luta pelo poder é prolongada e tende a tomar a forma de guerra civil entre as forças revolucionárias e reaccionárias" (Idem : 90). Em 1964, quando da cisão entre os comunistas que conduzira à constituição deste grupo, criticarase desde logo a teoria khrushcheviana da "passagem pacífica para o socialismo " e "a elevação da política de coexistência pacífica ao plano da linha geral do movimento comunista”, contrapondo-lhe a impossibilidade de uma política "de conciliação de classes", bem como o carácter necessário e criador da revolução armada (RP, 1964, 1: 1-2).

Após a vaga repressiva que dizimou os membros activos do CMLP no interior do país, de entre as facções que pretenderam assumir o seu legado foi o grupo organizado em tomo do jornal $O$ Comunista, localizado principalmente na emigração residente em França, que retomaria de forma mais extrema a defesa 
de uma solução assente no papel dinamizador da luía armada. A sua linha de orientação, algo heterodoxa pois combinava influências de tipo guevarista com a adesão a alguns dos fundamentos do maoísmo, integrava alguns princípios que inseriam a acção armada, por vezes, naquilo que se pode hoje considerar uma deriva espontaneísta. Como exemplo, declarava-se logo em 1968 que "a nossa ideologia não existe se não desencadearmos a luta armada”, ou que "a nossa linha de acção é organizar e consciencializar a classe operária, e posteriormente lançar a acção violenta nos locais de trabalho, nos campos, etc. ” (C, 1968, 1: 5-6), defínindo-se ainda a utilização da violência "como factor catalisador" (C, 1973, 11: 4). Este estilo de atitude leva o jornal, em diversos números, a oferecer receitas para o fabrico doméstico de armas a utilizar em acções violentas de guerrilha urbana e em manifestações, como o cocktail Molotov ou a bola de pingue-pongue. Para esta é sugerido mesmo um conjunto de utilizações práticas: "pode ser usada para sabotagem de automóveis (põe-se dentro do depósito de gasolina, passado algum tempo o automóvel explode); pode provocar agitação em recintos fechados (espectáculos de cinema, teatro, etc.); pode provocar um incêndio nos depósitos da Shell ou da Sacor” (C, 1969, 2: 3). Em qualquer caso, considera-se sempre ser a violência "o elemento formador da estrutura de qualquer sociedade " e que " a linha de demarcação entre os revolucionários e os reformistas encontrase na utilização de novas formas de luta, no emprego da violência revolucionária contra a violência burguesa” (C, 1970, 6: 3).

Com algumas nuances, $O$ Grito do Povo e a OCMLP retomarão, já no interior do país, esta mesma linha, defendendo, uma vez mais, "a insurreição popular armada " e a "guerra popular para a tomada do poder " (GP, 1971,1: 3) como sendo as únicas vias para uma mudança revolucionária da sociedade portuguesa. Como consequência desta orientação, em 1973 produzirão um forte ataque à realização do III Congresso da Oposição Democrática, que apodam pejorativamente de "congresso cor-de-rosa ", devido ao que consideraram haver sido o compactuar dos seus promotores com “os métodos legalistas da burguesia " (GP, 1973,9:11). Aos seus militantes recorda, utilizando uma transcrição livre de palavras atribuídas a Mao Tsé-Tung, que "todo o homem em de morrer um dia, mas nem todas as mortes têm o mesmo significado (...): morrer pelos interesses do povo tem mais peso que o monte Tai, mas esforçar-se ao serviço dos fascistas (...) pesa menos do que uma pena" (GP, 1972, 3: 8). Alguns dos antigos activistas do grupo recordam actualmente a importância atribuída a este aspecto, que passava pela organização de um pequeno sector armado e pela realização ocasional de actividades básicas de preparação militar.

O MRPP considerava também que "só pela luta revolucionária de massas, em especial pela luta armada, as classes exploradas (...) poderão derrubar o 
Estado burguês e instaurar o Estado proletário ” (LP, 1971, 6: 19), criticando certas formas de mobilização, utilizadas nomeadamente pelos sindicatos, que considera recuadas e completamente inúteis. Neste sentido, o Luta Popular declara a dada altura que "não é com piqueniques que a classe operária esmagada pela agressão do capital celebra o Io de Maio", sendo antes "no combate que o proletariado reconhece a sua festa ” (LP, 1971,7:4). No início de 1974 previa ainda "grandes, duras e sangrentas batalhas" (LP, 1974,15-16: 13). A tomada por sectores ligados ao movimento, concretizada em 1971, da direcção da revista O Tempo e o Modo, transformaria esta num espaço de divulgação de iniciativas de carácter violento, ocorridas nas mais diversas paragens e reputadas como possuindo um carácter revolucionário.

Por último, a Liga de União e Acção Revolucionária (LUAR), fundada em 1967 e centrada na figura carismática e voluntariosa de Herminio da Palma Inácio, procedeu, apesar de alguma relação de proximidade com os socialistas, à defesa absoluta da acção armada como principal forma de alcançar a queda do regime, considerando que, sem ela, "não podemos esperar que o regime cairá por si, nem que os trabalhadores poderão esperar que o poder lhes seja entregue numa bandeira" (F, 1974, 2: 43). Vocacionada para iniciativas de grande espectacularidade, por vezes destinadas a obter fundos para a propaganda contra o regime ou a desacreditá-lo, excluiu, por isso, quaisquer veleidades organizativas de integração da acção armada com o movimento de massas. Mas nem por isso deixou de ser reconhecida, por outros sectores da oposição, como força que indicava, porventura, o único caminho que a dada altura parecia possível.

3. A importante vertente pacifista dos anos sessenta não chegou a afirmar-se em Portugal, salvo como fenómeno pontual. Muitos dos milhares de jovens que, em Agosto de 1971, simulavam os sinais e os comportamentos dos hippies de São Francisco no festival de música rock de Vilar de Mouros, aplaudiram de pé, meses depois, em Cascais, a declaração de apoio à guerra de emancipação das colónias produzida pelo contrabaixista de jazz Charlie Haden. Para amplos sectores, principalmente para aqueles mais directamente empenhados nas actividades de oposição, a verbalização da paz funcionava como metáfora da rejeição da violência do Estado, e como factor de contestação de um conflito colonial que parecia não ter fim, sob uma paisagem marcada pela vontade de eliminar os bloqueios impostos pelo regime. A guerra, enquanto modalidade extrema da violência revolucionária, permaneceu, assim, como um cenário redentor, por vezes possível, outras desejável. E a utilização da força das armas como forma de pôr termo ao regime condicionou, a uma escala que ainda se 
encontra por esclarecer de forma sustentada, a formação do movimento que o derrubaria.

A imagem de recorte romântico do capitão Salgueiro Maia, de pé e segurando um megafone sobre o tanque que apontava o canhão ao edifício do Quartel do Carmo, no qual se haviam entrincheirado os últimos representantes do regime que estava a ser deposto, corresponderia ao epílogo de um processo de contestação armada do Estado Novo que foi acelerado nos seus derradeiros anos. Vitoriosa, embora não da forma que concebera, a acção revolucionária podia agora guardar as balas, e, por alguns dias, de dedos em vê, os seus partidários adornaram com cravos os canos das espingardas.

\section{Bibliografia}

\section{Publicações Periódicas:}

O Anti-Colonialista (AC), Avante! (A), Comércio do Funchal (CF), O Comunista (C), Folha Comunista (FC), Fronteira (F), O Grito do Povo (GP), Liberdade (L), Luta Popular (LP), O Militante (M), Passa Palavra (PP), Portugal Socialista (PS), Os Povos das Colónias Vencerão (PCV), Revolução Popular (RP), Seara Nova (SN), O Tempo e o Modo (TM).

\section{Fontes e obras de referência:}

III Congresso da Oposição Democrática: Conclusões (1973). Lisboa: Seara Nova. ALEGRE, Manuel (2000) - Praça da Canção - O Canto e as Armas. Lisboa:

Publicações Dom Quixote.

ANDERSON, Benedict (1983) - Imagined Communities. Reflections on the Origin and Spread of Nationalism. London: Verso.

APPADURAI, Aijun (2004) - Dimensões Culturais da Globalização. A Modernidade sem Peias. Lisboa: Teorema (ed. orig.: 1996).

ARENDT, Hannah (1985) - Da Violência. Brasília: Editora Universidade de Brasília [ed. original: 1969].

ARÓSTEGUI, Júlio; BUCHRUCKER, Cristina; e SABORIDO, Joige (2001)-El Mundo Contemporáneo: Historia y Problemas. Barcelona: Biblos.

BAGANHA, Maria Ioannis (2000) - "A Emigração Portuguesa no Pós II Guerra Mundial”, Portugal Contemporâneo. Coord, de António Costa Pinto. Madrid: Sequitur. 213-231.

BEBIANO, Rui (2002) - “As Esquerdas e a Oposição à Guerra Colonial”, inA Guerra do Ultramar: Realidade e Ficção. Actas do II Congresso sobre a Guerra Colonial, Lisboa: Editorial Notícias - Universidade Aberta. 293-313. 
- (2003) - O Poder da Imaginação. Juventude, Rebeldia e Resistência nos Anos 60. Coimbra: Angelus Novus.

BERMAN, Paul (1996) - A Tale ofTwo Utopias : The Political Journey of the Génération of 1968. New York: Norton.

BOYA, Lucien (2000) - La Mythologie Scientifique du Communisme. Paris: Les Belles Lettres.

BOYM, Svetlana (2001) - The Future of Nostalgia. New York: Basic Books.

BRITO, Casimiro de (1974) - Jardins de Guerra. Lisboa: Assírio \& Alvim.

Cadernos Necessários. 1969-1970 (1975) - Porto: Afrontamento.

CARDINA, Miguel (2005) - A Politização do Meio Estudantil Coimbrão durante $o$ Mareelismo. Dissertação de Mestrado. Coimbra: edição do autor.

CAUTE, David(1988) - TheFellow-Travellers. IntellectualFriendsof Communism. London: Yale University Press.

- (1988b) - Sixty-Eight. The Year of the Barricades, London: Hamish Hamilton.

CHANG, Jung; HALLIDAY, Jon (2005) - Mao. A História Desconhecida. Lisboa: Bertrand.

Citações do Presidente Mao (1972) - Pequim: Edições em Línguas Estrangeiras.

CLECAK, Peter (1973) - Radical Paradoxes: Dilemmas of the American Left: 1945-1970. New York: Harper and Row.

COHN-BENDIT, Daniel (1988) -1968: A Revolução Que Tanto Amámos. Lisboa: Dom Quixote.

COHN-BENDIT, Daniel e Gabriel (1968) - Obsolete Communism The Left Wing Alternative. London: Anffe Deutsch.

COOK, Pam (2005) - Screening the Past. Memory and Nostalgia in Cinema. London: Routledge.

CUNHA, Luís, A Nação nas Malhas da sua Identidade. O Estado Novo e a Construção da Identidade Nacional. Porto: Afrontamento.

CUNHAL, Álvaro ( 1971 ) - O Radicalismo Pequeno-Burguês de Fachada Socialista. 2. ${ }^{\mathrm{a}}$ ed. S.I.: Avante!

- (1979)- Rumo à Vitoria. As Tarefas do Partido na Revolução Democrática e Nacional, 2a. ed. Lisboa: Avante!

DALTON, Russei, e KECHLER, M. (1990) - Challenging the Political Order: New Social and Political Movements in Western Democracies. Oxford, Polity Press.

DEKOVEN, Marianne (2004) - Utopia Limited. The Sixties and the Emergence of the Postmodem. London: Duke University.

Diálogo ou Violência? (1965) - autores vários. Lisboa: Publicações Europa-América. DRESSEN, Mamix (2000) -Del 'amphi à l'établi. Les étudiants à l'usine (19671989). Paris: Belin. 
DUBOIS, Jean-Paul (2005) - Entrevista ao suplemento "Mil Folhas", Público, 5 de Novembro.

ENZENSBERGER, Hans Magnno ( 1998) - Perspectivas da Guerra Civil. Lisboa: Relógio d'Água.

FARBER, David (1994a) - The Age of Great Dreams: America in the 1960s. New York: Hill and Wang.

- (1994b) - The Sixties: From Memory to History. Chapei Hill: University of North Carolina Press.

FERRY, Luc, e RENAUT, Alain (1988) - La Pensée 68. Essai sur l'anti-humanisme contemporain. Paris: Gallimard.

FEUER, Lewis (1969) - The Conflict of Générations : The Character and Signijicance of Student Movements. New York : Basis Books.

FINK, Carole; GASSERT, Philipp; JUNKER, Detlef (1988) - 1968. The World Transformed, Cambridge: Cambridge University Press.

FURET, François (1996) - O Passado de uma Ilusão. Ensaio sobre a ideia comunista no século $X X$. Lisboa: Presença.

FURTER, Pierre (1995) - Mondes Rêvés. Formes et Expressions de la Pensée Imaginaire. Lausane: Delachaux et Nestlé.

GALVÃO, Henrique (1961) - Proclamação da Frente Antitotalitária dos Portugueses Livres no Estrangeiro. S.I.: s.ed.

GITLIN, Todd (1987) - The Sixties. Years of Hope, Days of Rage. New York: Bantam Books.

GOMBIN, Richard (1972) - As Origens do Esquerdismo. Lisboa: Publicações Dom Quixote.

GUERRA, João Paulo (1993) - Memória das Guerras Coloniais, Porto: Afrontamento.

"Carlos e Isabel - Acções explosivas", depoimentos transcritos por José Freire Antunes em A Guerra de África, 1961-1974, vol. II, Lisboa, 1995, pp. 907-920.

HOURMANT, François (2000) - Au Pays de l Avenir Radieux. Voyages des intellectuels français en URSS, à Cuba et en Chine populaire. Paris: Aubier.

HUTCHEON, Linda ( 1988) - A Poetics ofPostmodemism. New York: Routledge.

- (1998) - "Irony, Nostalgia, and the postmodem" Internet (17.03.2005): <http:/ /www. library. utoronto. ca/utel/criticism/hutchinp. html>.

HUYSSEN, Andreas (2003) - Présent Pasts. Urban Palimpsests and the Politics of Memory. Stanford: Stanford University.

JAMESON, Fredric (1994) - The Seeds oflïme. New York: Columbia U. Press.

KOPKIND, Andrew (1966) - Thoughts of the Young Radicais, New York: Pitman.

KOSS, Kristin (2002) - May '98 and Its Afterlives. Chicago: University of Chicago Press. 
KURLANSKY, Mark (2004) -1968. El año que commocionó al mundo. Madrid: Ediciones Destino.

LOURENÇO, Eduardo (2001) - A Europa Desencantada. Para uma Mitologia Europeia. Lisboa : Gradiva.

MARQUES, Femando Pereira (2005) - A Praia sob a Calçada. Maio de 68 e a «Geração de 60». Lisboa: Âncora.

MARWICK, Arthur (1998)- The Sixties. Cultural Révolution in Britain, France, Italyandthe United States, c. 1958-C.1974. Oxford : Oxford University Press.

MELUCCI, Alberto (1996) - Challenging Codes. Collective Action in the Information Age. Cambridge: Cambridge University Press.

MELO, Daniel (2001) - Salazarismo e Cultura Popular (1933-1958). Lisboa: Imprensa de Ciências Sociais.

Monsanto (1947), Lisboa: SNI, 1947.

MORIN, Edgar ( 1969) - "Uma revolução sem rosto", in Maio 68: Inventário de uma Rebelião, ob. colectiva. Lisboa: Moraes.

NARCISO, Raimundo (2000) - A.R.A. - Acção Revolucionária Armada. A história secreta do braço armado do PCP, Lisboa: Dom Quixote.

NUNES, Adérito Sedas (2000). Antologia Sociológica. Selecção e prefácio de Maria Filomena Mónica. Lisboa: Imprensa de Ciências Sociais.

OELGART, Bemd (s.d.) - Ideólogos e ideologias da Nova Esquerda. Lisboa: Presença. PEREIRA, José Pacheco (2005) - O Prisioneiro, vol. V de Álvaro Cunhal. Uma Biografia Política. Lisboa: Temas e Debates.

PRÉEL, Bernard (2000) - Le Choc des Générations. Paris: La Découverte.

RABY, Dawn Linda (1964) - “A oposição no exílio e a guerra colonial”, Vértice. 58, II série. 37-40.

Resenha Histórico-Militar das Campanhas de Africa (1961-1974). Io Volume. Enquadramento Geral (1988). Lisboa: Estado-Maior do Exército.

RODRIGUES, Francisco Martins (s.d.) - Elementos para a História do Movimento Operário e do Partido Comunista em Portugal. Edição dactilografada, s. 1. ROSAS, Femando (1994) - O Estado Novo (1926-1974). Vol. VII da História de Portugal. Dir. De José Mattoso. Lisboa: Círculo de Leitores.

ROWNTREE, John e Margaret (1968) - "Youth as class", Internacional Socialist Journal, February.

RUBIN, Jerry (1970) - Do It! Scénarios of the Révolution. New York: Simon and Schuster.

RUYER, Raymond (1988) - L'Utopie et les utopistes. Brionne: G. Monfort [ed. original: 1950].

SANTOS, Boaventura de Sousa (1994) - Pela Mão de Alice. O Social e o Político na Pós-Modernidade. Porto: Afrontamento. 
SARTRE, Jean-Paul (2002) - Prefacio a. Les Damnés de la Terre. Paris: La Découverte [ed. orognal de 1961].

SCHEPER-HUGHES, Nancy; BOURGOIS, Philippe, eds. (2004) - Violence in War and Peace. Oxford: Blackwell.

TEIXEIRA, Rui de Azevedo (1998) - A Guerra Colonial e o Romance Português. Lisboa: Notícias.

VARON, Jeremy (2004) - Bringing The War Home. Revolutionary Violence in the Sixites and Seventies. Berkeley: University of California Press.

VENTURA, Cándida (1984) - O «Socialismo» que eu vivi. Lisboa: O Jornal.

VIRILIO, Paul (2000) - A Velocidade de Libertação. Lisboa: Relógio d'Água.

WILSON, Elizabeth (1997) - "Looking Backward. Nostalgia and the City", Imagining Cities. Scripts, Signs, Memories (ed. Sallie Westwood e John Williams). London-New York: Routledge. 127-139.

WILliams, Raymond (1989) - The Politics of Modemism. Against New Conformists. London: Verso. 